\title{
Zenginleştirilmiş Kütüphanelerdeki Mevcut Durum ve Uygulamaların Analizi: Ankara'nın Çankaya İlçesindeki 12 Okulda Gerçekleştirilen Araştırmanın Sonuçları
}

\author{
Analysis of Existing Conditions and Practices in Enriched Libraries: Results of a \\ Research Conducted in 12 Schools in Cankaya District of Ankara
}

Tolga Çakmak* ve Şahika Eroğlu**

$\ddot{O}_{z}$

Okul kütüphaneleri, ögrencilerin, ebeveynlerin, öğretmenlerin, idarecilerin ve diğer okul personelinin bilgi ihtiyaçlarını karşılayacak hizmetler sunan kütüphanelerdir. Bu kütüphaneler temel işlev olarak müfredat programını desteklemektedir. Bireylerin yaşamlarında ögrenmenin gerçekleştiği dönemlerde yer alan bu kütüphaneler güncel teknoloji ve olanakların sunulduğu, hedef kitlesinin beklentilerine ve karakteristiklerine uygun hizmetlerin ve ortamların sağlandĭ̆ yerler olarak da değer taşımaktadır. Türkiye’de Millî Ĕ̆itim Bakanlı̆̆ı tarafindan koordine edilen z-kütüphane projesiyle okullardaki kütüphanelerin sosyal öğrenme ortamına dönüştürülmesi hedeflenmiştir. Bu bağlamda okul kütüphanelerinin teknolojik ve modern araçlarla donatıldı ̆̆ görülmektedir. Bu çalışmada Ankara'nın Çankaya ilçesindeki okullarda bulunan z-kütüphanelerin mevcut durumlarının ve kullanımlarının betimlenmesi amaçlanmıştır. Belirlenen amaç çerçevesinde Çankaya'da bulunan 12 okuldaki z-kütüphaneler analiz edilmiştir. Bir durum çalışmasının gerçekleştirildiği bu araştırma kapsamında veriler; okul müdürleri, müdür yardımclları ve kütüphaneden sorumlu ögrretmenlerle yapılan yart yapılandırılmış görüşmeler ve gözlemlerle toplanmıştır. Çalışma sonuçlarında analiz edilen 12 okulda z-kütüphanelerin mekânsal alan olarak standartlara uygun olmasına karşın bu durumun ögrenci sayılarına göre değişkenlik gösterebildiği, kütüphanelerin kuruluş amaçlarına uygun kullanımında projelerin, uluslararası programlara uyumluluk sürecinin, yönetici ve ögrretmen farkındalı̆̆ının etkili olduğu anlaşılmıştır. Diğer yandan okullarda bu kütüphanelerin sürdürülebilirliğine yönelik sorunların yaşandığ tespit edilmiştir. Çalışmanın son bölümünde ise z-kütüphanelerin sürdürülebilirliği ve gelecek çalışmalara yönelik önerilerde bulunulmuştur.

Anahtar Sözcükler: Okul kütüphaneleri; zenginleştirilmiş kütüphaneler; z-kütüphaneler; kütüphane yönetimi; kütüphane kullanımı.

\footnotetext{
* Dr. Öğr. Üyesi, Hacettepe Üniversitesi Bilgi ve Belge Yönetimi Bölümü. E-posta: tcakmak@ hacettepe.edu.tr Assist. Prof., Hacettepe University Department of Information Management, Turkey

** Dr., Hacettepe Üniversitesi Bilgi ve Belge Yönetimi Bölümü. E-posta: sahikaeroglu@ hacettepe.edu.tr

Dr., Hacettepe University Department of Information Management, Turkey
}

Geliş Tarihi - Received: 21.10.2019

Kabul Tarihi - Accepted: 16.03.2020 


\section{Abstract}

School libraries are libraries that provide services to meet the information needs of students, parents, teachers, administrators and other school staff. As the main function, these libraries support the curriculum. These libraries, which take place in the periods of learning in individuals' lives, are also places where current technology and facilities are provided and services and environments are provided in accordance with the expectations and characteristics of the target audience. The school libraries in Turkey are planned to be transformed into social learning places within the scope of the enriched libraries project (zkütüphane) coordinated by the Ministry of Education. In this regard, it is seen that the school libraries are equipped with technological facilities and streamlined furnishings. In this study, it is aimed to describe the current situation and usage of z-libraries in schools in Chankaya district of Ankara. For this purpose, 12 z-libraries in schools at Çankaya, Ankara were analyzed. In the context of this case study, which is one of the qualitative research methods, data were collected through semi-structured interviews and observations with school principals, assistant principals, and teachers in charge of the library. The study results reflect that z-libraries are spatially compliant with the standards, however, this case may vary depending on the number of students. It was understood that compliance with international programs, teacher and principal awareness, and projects are the factors that provide efficient and expected use of $z$-libraries. On the other hand, it has been detected that there are problems regarding the sustainability of these libraries. In the last part of the study, recommendations and future studies that can be conducted are addressed.

Keywords: School libraries; enriched libraries; z-libraries; library management; library use.

\section{Giriş}

Okul kütüphaneleri öğrencilerin öğrenim hayatları boyunca başarıya ulaşma, anlama, eğitime ve öğretim faaliyetlerine destek verme açısından katkı sağlayan kurumlardır. Okul kütüphanesi öğrenmenin merkezinde yer alarak yenilik, merak ve problem çözmeyi teşvik eden bir mekândır. Eğitim programının kalbi olarak betimlenen okul kütüphanesi, öğrencilerin yetenekli ve hevesli okuyucular olmalarına, etraflarındaki dünya hakkında bilgi sahibi olmalarına ve gelecek koşullarında hayatta kalmaya yönelik imkânlar sağlayan bir yapı olarak algılanmıştır (Gaver, 1958, s.16). Okulun sosyal ve kültürel rolünün önemli bir bileşeni olan okul kütüphanesi her türlü okuma, kültürel etkinlik, bilgiye erişim, bilgi yaratma, derin düşünme ve canlı tartışmalar için merkezi bir nokta olabilmektedir. Gelişen teknolojik imkânlar birçok alanda beraberinde firsatlar sunmaktadır. Yaşanan teknolojik dönüşümler okul kütüphanelerinin de geçmişten farklı olmaları gerekliliğini ortaya çıkarmıştır. Günümüz dünyasında artık sadece "var olmaları" yetmeyen okul kütüphanelerinin geleneksel ve çağdaş sistemlerin harmanlanması ile oluşan yapılarla öğrencileri kendilerine çekmesi gerekmektedir. $\mathrm{Bu}$ anlamda ortaya çıkan yeni yaklaşımlarda okul kütüphaneleri, geleneksel hizmetlerinin yanı sıra öğrencilerin eğitimlerine teknolojik imkânlar ile katkı sağlayabilen ve mekânsal tasarımlarıyla da öğrencilerin farklı ihtiyaçlarını karşılayabilen mekânlar haline dönüşmektedir.

Okul kütüphanelerini dijital dönüşüm gereksinimleri çerçevesinde zenginleştirme programlarının ülkelerin eğitim stratejilerine yerleştirildiği görülmektedir. Literatürde okul kütüphanelerinde teknoloji kullanımına yönelik uygulamaların ele alındığı çalışmalar yer 
almaktadır (DeMarco, 2014; IFLA, 2015; Kuno, 2011). Benzer şekilde Türkiye'de de okul kütüphanelerine yönelik çalışmalar yapılmakta; bu kapsamda Millî Eğitim Bakanlığı tarafından gerçekleştirilen proje ve uygulamalar öne çıkmaktadır. Türkiye'deki okul kütüphanelerine yönelik proje ve uygulamalardan biri de z-kütüphane projesidir. 2014 y1lından bu yana Millî Eğitim Bakanlığı tarafından yönetilen proje kapsamında okullardaki kütüphanelerin işlevlerinin çağın gereklerine uygun şekilde geliştirilmesi hedeflenmektedir. Mili Eğitim Bakanlığının (MEB) zenginleştirilmiş kütüphaneler (z-kütüphane) için oluşturduğu web sayfasında zkütüphane, "estetik ve ergonomik tasarımıyla öğrencilerin okullarda bilgiyi sevme, öğrenme ve dinlenme etkinliklerine imkân veren sosyal etkinlik alanıdır" şeklinde tanımlanmaktadır (Milli Eğitim Bakanlığı, 2016). Bu tanımdan yola çıkarak z-kütüphanelerin temel hedefinin okul kütüphanelerini sosyal öğrenme alanlarına dönüştürmek olduğu söylenebilir. Millî Eğitim Bakanlığının “Okullar Hayat Olsun” projesi kapsamında z-kütüphane çalışmalarına başlamış olması da bu hedefe dair varsayımı desteklemektedir.

$\mathrm{Bu}$ çalışmada literatür çerçevesinde, teknolojik gelişmeler bakımından okul kütüphanelerinde meydana gelen değişimlerin betimlenmesi, konunun Türkiye bağlamında bir yansıması olan z-kütüphanelerin mevcut durumunun ve yönetiminin Ankara ili Çankaya ilçesi kapsamında incelenmesi amaçlanmaktadır. Bu amaç doğrultusunda çalışmada ilk olarak okul kütüphanelerine yönelik literatür değerlendirilmektedir. Uluslararası literatür Web of Science veri tabanında yer alan yayınlardaki anahtar kelime birlikteliğine yönelik a $\breve{g}$ analizi ile değerlendirilmiştir. Sonrasında Türkiye'de okul kütüphanelerine yönelik çalışmalar ele alınmıştır. Daha sonra çalışma metodolojisi sunulmuş ve ardından gerçekleştirilen araştırma kapsamında Ankara ili Çankaya ilçesinde yer alan 12 z-kütüphaneye yönelik bulgu ve değerlendirmelere yer verilmiştir. Çalışmanın son bölümünde ise bulgulardan hareketle sonuç ve öneriler sunulmuştur.

\section{Okul Kütüphaneleri: Literatür Değerlendirmesi}

Çalışmada okul kütüphanelerine yönelik çalışmaları değerlendirmek için Web of Science (WoS) veri tabanında yer alan okul kütüphaneleri ile ilgili çalışmalar ve konular belirlenmeye çalışılmıştır. Bu doğrultuda başlığında ve konu bölümünde "okul kütüphanesi” ya da "okul kütüphaneleri" geçen bütün yayın künyelerine 10 Ekim 2019 tarihinde yapılan arama ile erişilmiştir. Arama sonucunda 1364 yayın künyesine erişim sağlanmıştır. Bu künyelerden ilk olarak Kütüphanecilik ve Bilgi Bilim alanıyla ilgili olan çalışmalar filtrelenmiş ve bu işlem sonucunda 969 yayın künyesi belirlenmiştir. Bu künyeler sekme ile ayrılmış UTF 8 uyumlu metin dosyası olarak indirilmiş ve anahtar kelimelere ilişkin sütunlar incelenerek ek almış ve aynı anlamdaki kelimeler standart bir hale getirilmiştir. Bu işlemin ardından materyal türü olarak makale, kitap bölümü ve bildiri türündeki yayınlardan anahtar kelimeler bölümü bulunan kaynaklar araştırmaya dâhil edilmiştir. Son işlem olarak da elde edilen künyelerden tıp okulu (medical school), işletme okulu (business school) ve hukuk okulu (law school) gibi kapsamla ilgili olmayan çalışmalar veri setinden çıkarılmıştır.

Literatür değerlendirmesi kapsamında WoS veri tabanında okul kütüphaneleriyle ilgili çalışmaların konu dağılımını belirleyebilmek için yayınların yazarları tarafından belirlenmiş olan anahtar kelimeleri üzerinde birliktelik analizleri yapılmıştır. Bu kapsamda öncelikle 969 yayından 360'ında anahtar kelime olduğu belirlenmiştir. Ardından bu 360 yayından veri standardizasyonu 
ve düzenleme işlemleri sonucunda elde edilen 192 yayındaki 785 anahtar kelimeden en az üç kez eşleşmiş olan kelimeler VosViewer yazılımıyla haritalanmıştır (Şekil 1).

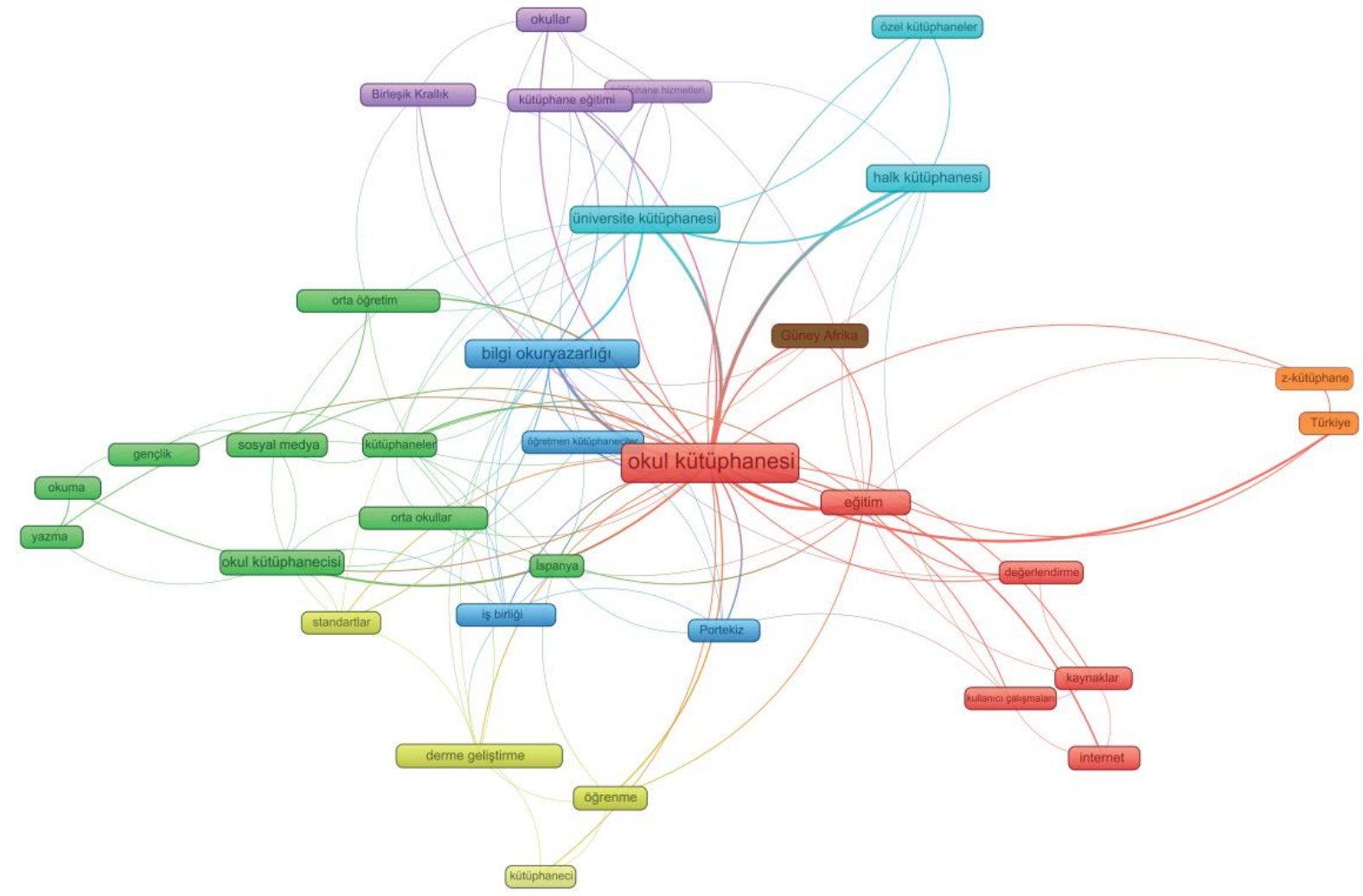

Şekil 1. Yayınların konu gruplarına göre dağılımı

Yazar anahtar kelimelerinin birlikteliklerine yönelik analiz sonuçlarında WoS veri tabanında okul kütüphaneleriyle ilgili yayınlar on iki kümeye ayrılmıştır. Bu kümeler içerisinde okul kütüphanelerinden sonra en fazla link uzunluğuna sahip olan anahtar kelimeler; üniversite kütüphaneleri (17 eşleşme, link uzunluğu: 40), bilgi okuryazarlı̆g (23 eşleşme, link uzunluğu: 37), halk kütüphaneleri (16 eşleşme, link uzunluğu: 29), eğitim (12 eşleşme, link uzunluğu: 27) ve kütüphanelerdir (9 eşleşme, link uzunluğu: 15).

Şekil 1'e göre ilk grupta (yeşil renkli) okul kütüphanecileri, ortaöğretim, büyüme çağındaki çocuklar, sosyal medya, okuma ve yazma gibi kelimeler yer almaktadır. Bu kapsamda okul kütüphanecilerinin eğitimdeki rolleri ve belirli bir konudaki görüşlerine yönelik araştırmalar yapılmıştır (Dawkins ve Gavigan, 2017; Dow ve Lakin, 2012; Lo ve diğerleri, 2019; Valenza ve Hobbs, 2016). Okul kütüphanelerinin ortaöğretim ile olan boyutunda ise bilgi okuryazarlığı ile bağlantı kuran çalışmalar dikkati çekmektedir (Baji, Bigdeli, Parsa ve Haeusler, 2018; Foo ve diğerleri, 2014). Ayrıca okul kütüphanelerinin okumaya yönelik motivasyon kazandırma işlevleriyle ilgili çalışmalar da literatürde yer almaktadır (Fletcher, Grimley, Greenwood ve Parkhill, 2012; Loh, 2016). Sosyal medya boyutunda ise çalışmalarda okul kütüphaneleri ile Wikipedia ve blogların okul kütüphanelerinde kullanımı ve dijital hizmetler ile okul kütüphanelerinin sosyal medya paylaşımları ele alınmıştır (Brown ve Hill, 2009; Faba-Pérez ve Infante-Fernández, 2019; Fitzgerald, 2009; Jones, Downs ve Jenkins, 2015; Pirola ve diğerleri, 2015; Sudhier ve Priya, 2017). 
Okul kütüphaneleri ile ilgili çalışmalardaki ikinci grupta (kırmızı renkli) eğitim, değerlendirme, kullanıcı araştırmaları ve internet kelimeleri bulunmaktadır. Bu gruptaki internet ve ilgili anahtar kelimeler okulların web sayfalarına yönelik analizlerin yapıldığ 1 çalışmalarda kullanılmıştır (Clyde, 2004; Wang, Shen, Chen ve Wedman, 2011). Kullanıcı araştırmaları kapsamında ise okul kütüphanelerinde sunulan hizmetlere ve web analitiğine yönelik çalışmalar yapılmıştır (Debus-López ve diğerleri, 2017; Wang ve diğerleri, 2011). Bu grupta ayrıca okul kütüphanelerinin genel durumunu, bilgi okuryazarllğı eğitimlerini değerlendiren, bilgi kaynaklarını ve değerlendirme araçlarını konu alan çalışmalar da bulunmaktadır (Farmer ve Safer, 2019; Gildersleeves, 2006; Martins ve Martins, 2012; Onyebuchi ve Ngwuchukwu, 2013).

Okul kütüphaneleriyle bağlantılı konulardan biri bilgi okuryazarlığıdır. Bu bağlamda çalışmalarda öğrencilere bilgi okuryazarlığı becerilerinin öğretilmesi, üniversite kütüphanelerinin ortaöğretim öğrencilerine bilgi okuryazarlığı becerilerini kazandırmadaki rolleri, belirli bir bölgedeki okul kütüphanelerinin karşılaştı̆̆ zorluklar ve okul kütüphanelerinde bilgi okuryazarlı̆ğ eğitimine değinilmiştir (Foo ve diğerleri, 2014; Jorosi ve Isaac, 2008; Paton-Ash ve Wilmot, 2015; Tedd, Ellis, Lonsdale ve Armstrong, 2006). Üçüncü grupta (mavi renkliayrıca iş birliği, ögretmen kütüphaneciler ve Portekiz kelimeleri bulunmaktadır. İş birliği boyutunda okul kütüphanelerinin tasarımında ve karar verme süreçlerinde okul kütüphanecileri, öğretmen kütüphaneciler ve yöneticiler arasında iş birliği yapılmasını öneren ve okul kütüphanecilerinin genişleyen rollerini konu alan çalışmalar bulunmaktadır (Hughes, Bland, Willis ve Burns, 2015; Lo ve Chiu, 2015). Bu kapsamda ayrica okul kütüphaneleri ile halk kütüphaneleri arasındaki kaynak paylaşımı ele alınmıştır (Baker, Smith, Shea ve Wu, 2014). Bununla birlikte öğretmen kütüphanecilerin sahip olması gereken beceriler ve öğrencilere bilgi okuryazarlığı becerilerinin kazandırılmasındaki rolleri de araştırılmıştır (Aisah, Abrizah, Aspura ve Dollah, 2018; Osadcbe, Babarinde, Ekere ve Dike, 2018; Ragle, 2011).

Bir diğer konu grubunda ise koleksiyon geliştirme, standartlar, eğitim ve kütüphaneciler anahtar kelimeleri yer almaktadır. Koleksiyon geliştirme kapsamında bir önceki grupta yer alan halk kütüphaneleriyle yapılabilecek iş birliğine yönelik çalışma ile okul kütüphanelerindeki belirli kaynakların içeriklerine yönelik araştırmalar öne çıkmaktadır (Brissett, 2011; Oltmann, 2015). Bir diğer anahtar kelime olan standartlar ile ilgili de çalş̧malarda okul kütüphaneleri için geliştirilen standartların değerlendirildiği görülmüştür (Ahlfeld, 2019; Gerrity, 2018; Rumberger, 2018; Udina, 2014).

Şekil 1'de sunulan konu grupları arasında bilgi hizmetleri, kütüphane eğitimi, Birleşik Krallık ve okulları içeren bir grup da bulunmaktadır. Bu gruptaki çalışmalar arasında daha önceki gruplardaki kelimelerden ögretmen kütüphaneciler ile ilişkili bir çalışma bulunmaktadır. $\mathrm{Bu}$ çalışmada öğretmen kütüphanecilerin bilgi hizmetlerindeki rolleri incelenmiştir (Osadcbe ve diğerleri, 2018). Bunun yanı sıra bilgi hizmetleri çerçevesinde belirli bir bölgedeki okul kütüphanelerinin durumunu ve karşılaştıkları sorunları ele alan çalışmalar da bulunmaktadır (Tabassum, Batool, Ameen ve Hassan, 2019). Kütüphane eğitimiyle ilgili olarak ise bilgi okuryazarlığı ile bağlantılı çalışmaları değerlendiren yayınlar yer almaktadır (Johnson ve diğerleri, 2018; Reynolds, McClellan, Finley, Martinez ve Linares, 2016; Reynolds, 
Willenborg, McClellan, Linares ve Sterner, 2017). Ek olarak kütüphanelerde öğretim teknolojileri bağlamında da okul kütüphanelerinin web sayfaları incelenmiştir (Chu, 2013).

Bir diğer grupta ise akademik kütüphaneler, halk kütüphaneleri ve özel kütüphaneler bulunmaktadır. Bu bağlamda akademik kütüphanelerin okul kütüphaneleriyle olan iş birlikleri ve kütüphane eğitimlerine yönelik çalışmalara rastlanmaktadır (Groves, 2019; Reynolds ve diğerleri, 2017). Halk kütüphaneleriyle ilgili olarak da okul kütüphanelerinin halk kütüphanelerinden farkları ile maker (yaratıc1) hareketinin okullarda ve okul kütüphanelerinde uygulanmasına değinen çalışmalar yapılmıştır (Moorefield-Lang, 2014, 2019; Paiva ve Ferraz, 2018).

Şekil 1'deki bir başka konu grubunda ise Türkiye'deki z-kütüphane uygulamalarına yönelik çalışmalar bulunmaktadır. Bu kapsamda Türkiye'de okul kütüphaneciliğindeki gelişmeler, z-kütüphane analizleri ve okul kütüphanelerinin işlevlerine yönelik makale ve görüş yazıları bulunmaktadır (Akman ve Akman, 2017; Aslan, 2017; Önal, 2005; Öztürk ve Tağa, 2018).

Son olarak Güney Afrika'ya yönelik çalışmalar Şekil 1'de ayrı bir grup olarak verilmiştir. Bu konuda Güney Afrika'daki uygulamalar, karşılaşılan sorunlar ve bilgi okuryazarlığ çalışmalarının öne çıktığı anlaşılmaktadır (Fombad ve Jiyane, 2015; Paton-Ash ve Wilmot, 2015; Zinn, Stilwell ve Hoskins, 2016).

\section{Türkiye'de Okul Kütüphaneleri}

Türkiye'de okul kütüphaneleriyle ilgili çalışmalar genelde okul kütüphanelerinin gelişimi, yaşanan sorunlar, insan kaynakları ve derme yönetimine yoğunlaşmaktadır. Bunun yanı sıra Türkiye'de okul kütüphanelerinin koşullarının iyileştirilmesine yönelik yasal düzenlemeler ve yönetmelikler yayımlanmıştır. Karşılaşılan sorunlarla ilgili çözüm önerilerinin geliştirilmesi konusunda da lisansüstü düzeyde çalışmaların yapıldığı ve Millî Eğitim Şûraları gibi etkinliklerin gerçekleştirildiği görülmektedir. Çalışmanın bu bölümünde Türkiye'de okul kütüphaneleri, uygulamalar ve kullanım analizleri, okul kütüphanelerinin organizasyonu ve zkütüphanelere yönelik uygulamalar bağlamında ele alınmaktadır.

\section{Okul Kütüphanelerindeki Uygulamalar ve Kullanım Analizleri}

Literatürde öğrencilerin okul kütüphanelerine yönelik yaklaşım ve algıları Türkiye'nin farklı illerinde yapılan araştırmalarla betimlenmeye çalışılmıştır. Bu doğrultuda ilkokul, ortaokul ve lise gibi farklı öğretim kademelerindeki öğrencilerin kütüphane kullanımı ve okuma alışkanlıkları incelenmiştir. Bu araştırmalara örnek olarak 2009 yılında Erzurum'da ilkokul öğrencilerinin okul kütüphanelerini ve sınıf kitaplıklarını kullanma düzeylerini analiz eden çalışma gösterilebilir. 58 okuldaki yönetici ve öğretmen ile gerçekleştirilen araştırmada okul kütüphanelerinde mesleki deneyime sahip insan kaynağ1, bütçe ve derme yönetimi gibi sürdürülebilirlikle ilgili iyileştirmelere ihtiyaç duyulduğu saptanmıştır (Şahin, İşcan ve Maden, 2009). Kocaeli'nin İzmit ilçesinde bir özel ve 10 devlet okulundaki 66 öğretmen ve farklı eğitim kademelerindeki 300 öğrencinin kütüphane kullanımlarının analiz edildiği bir diğer çalışmada okul kütüphanelerinin mesleki standartların çok altında olduğu anlaşılmıştır (Aşıcı ve Özarslan, 2002). Kastamonu'da gerçekleştirilen başka bir araştırmada merkeze bağlı 10 köy ilkokulundaki 818 öğrenci ve 54 öğretmenden toplanan veriler değerlendirilmiştir. Sonuçlara 
göre kütüphaneler yalnızca kitap ödünç verme hizmetini yerine getirebilmekte ve bunun dışındaki hizmetleri sunmakta yetersiz kalmaktadır. Ayrıca araştırmadaki kütüphanelerde uzman insan kaynağ1 eksikliği de bulunmaktadır (Akbulut Güneş, 2013).

Literatürde ortaokul öğrencilerinin okul kütüphanelerini kullanımları da incelenmektedir. Bu kapsamda Mersin'in farklı ilçelerinde öğrenim gören 390 öğrencinin kütüphane kullanımlarının analiz edildiği bir araştırmaya göre okul kütüphanelerinin kullanım amaçlarında ilk sıralarda geleneksel kütüphanecilik hizmetleri yer almaktadır. Diğer yandan kütüphanede arkadaşını beklemek, arkadaşlarla vakit geçirmek, bilgisayar ve televizyon gibi araçlardan yararlanmak ve oyun oynamak gibi sosyal aktiviteler de öğrenciler tarafından kullanım amacı olarak belirtilmiştir. Çalışmada vurgulanan bu noktalar öğrencilerin kütüphaneleri sosyal bir ortam olarak düşündüklerini yansıtması açısından değerlidir (Şahbaz, 2012). Benzer bir araştırma, Ankara'nın Keçiören ilçesindeki iki okulda gerçekleştirilmiştir. 225 öğrenciye uygulanan anket sonuçları kütüphanelerde mekân ve profesyonel insan kaynağı iyileştirmelerine ihtiyaç duyulduğunu ve kütüphane kullanımında öğretmenlerin etkisinin olduğunu göstermiştir (Önal ve Alaca, 2015).

Liselerdeki kütüphaneler de araştırmalara konu olmaktadır. Bu çerçevede İzmir'in Buca ilçesindeki 23 lisedeki okul kütüphanesi, okul yöneticileri ve kütüphane sorumluları ile yapılan görüşmeler çerçeevesinde incelenmiştir. Araştırma sonuçları okul kütüphanelerinde derme, fiziksel alan, insan kaynakları ve aktiviteler açısından iyileştirmelere ihtiyaç duyulduğunu ortaya koymuştur (Polat ve Akkaya, 2015). Bir diğer çalışmada ise Ankara'daki 117 okul kütüphanesi analiz edilmiştir. 2004-2005 öğretim yılında yapılan bu çalışmada okul kütüphanesi dermelerinin Millî Eğitim Bakanlığı tarafından yürütülen 100 temel eser projesindeki eserlerle güçlendirilmesi gerekliliği vurgulanmıştır. Çalışmada ayrıca bilgi ve belge yönetimi bölümü mezunu kütüphanecilerin istihdamı, gerekli derme geliştirme çalışmalarının yapılmasında ve kullanıcı beklentilerinin karşılanmasında önemli görülmüştür (Önal, 2005). Ankara'nın Çankaya, Mamak ve Yenimahalle ilçelerinde 54 ilköğretim okulunda görev yapan 141 öğretmenin 100 temel esere ve okul kütüphanelerine yönelik düşüncelerinin araştırıldığı bir diğer çalışmada, öğretmenlerin okul kütüphanelerinin bu uygulamada yeterli işlevi taşımadığını düşündükleri ortaya çıkmıştır (Arıcan ve Yılmaz, 2010).

İlköğretim okullarındaki sınıf öğretmenlerinin eğitim programı ve okul kütüphaneleri ile ilişkili görüşleri de analiz edilen konular arasındadır. Bu kapsamda gerçekleştirilen bir çalışmada 2005-2006 öğretim yılında Ankara'nın farklı ilçelerinde yer alan yedi okuldan 118 öğretmene anket uygulanmıştır. Çalışma sonuçlarında okul kütüphanelerinin uluslararası standartlar düzeyine getirilmeden ve okullarda kütüphanelerin kurulmadan öğretim programlarının belirlenen hedeflere ulaşmasının mümkün olmayacağı belirtilmiştir (Dengiz ve Y1lmaz, 2007).

Literatürde üzerinde durulan bir diğer kurumsal yapı özel okullardaki kütüphanelerdir. Bu kapsamda Ankara, İstanbul ve İzmir'deki özel okul kütüphanelerinin mevcut koşulları değerlendirilmiştir. 37 okulun incelendiği çalışmaya göre özel okul kütüphaneleri uzman insan kaynağı istihdam etme, mekân olarak rahat ulaş1labilir bir konumda bulunma, bütçe ve bir politikaya sahip olma, kaynak sayısı gibi avantajlara sahiptir. Buna karşın bu kütüphanelerde çevrimiçi katalog, diğer kuruluşlarla iş birliği, insan kaynaklarının kurum içindeki statüsü ile ilgili yetersizlikler bulunmaktadır (Cevizbaş, 2003). Diğer yandan Ankara'daki üniversitelere 
bağlı özel ilköğretim okullarının kütüphanelerinde gerçekleştirilen bir araştırma, bu kütüphanelerdeki dermelerin, ilgili politikaların eksikliği nedeniyle nitelik açısından yetersiz kaldığını ortaya koymuştur (Tuna, 2005). Bir diğer çalışmada ise 15 kütüphaneciye uygulanan anket sonuçları paylaşılmıştır. Buna göre özel okullardaki kütüphanecilerin öğrencilerle etkili bir şekilde iletişim kurduklarını düşündükleri ve öğrencilerin iletişim sürecine daha etkin katılım göstermelerini bekledikleri belirtilmiştir. Ayrıca okul yönetimi, öğretmenler ve kütüphaneci iletişimindeki sorunların kütüphanecilerle öğrenci iletişimini de etkilediğine değinilmiştir (Koçak ve Çetintaş, 2015).

Özel okullardaki kütüphanelerin işlevlerine yönelik bir diğer çalışmada ise Sağlık ve Eğitim Vakfı / Amerikan Bord Heyeti Okullarındaki öğretmenler ve öğrencilere anket yapılmıştır. Öğretmen ve öğrencilere uygulanan bu anketin sonuçları okul kütüphanelerinin öğretmen ve öğrencilere güvenilir bilgi kaynaklarına ulaşma, ders içeriklerinin daha iyi anlaşılması, bilgisayar kullanımı, bilgiye erişimde analitik düşünme, bilgiye erişimde güven duyma, daha iyi çalışmalar yapma gibi konularda katkı sağladığı belirlenmiştir (Frank, 2012).

\section{Okul Kütüphanelerinin Organizasyon Yapısı ve Yasal Düzenlemeler}

Literatürde Türkiye'de okul kütüphanecilerinin rollerine yönelik çalışmalar da yapılmıştır. Bu doğrultuda okul kütüphanecilerinin birçok derse katkıda bulunma, hem öğretmenleri hem de öğrencileri yenilikler hakkında bilgilendirme, kütüphanenin etkin kullanımını sağlama, bilgi okuryazarlığı, yaratıcı uygulamalar ve dijital teknolojiler gibi konularda aktif rollerde bulunabilecekleri belirtilmiştir (Çakmak ve Önal, 2013; Durukan, 2015a; Erol Alkan, 2017; Güneş ve Güneş, 2014; Önal, 2015; Yüksel İleri, 2011). Bir diğer araştırmada ise yöneticilerin farkındalık ve bilgi eksikliklerinin kütüphanenin ve kütüphanecinin okul içerisindeki yerinin belirlenememesine neden olduğu saptanmıştır (Önal ve Ekici, 2012).

Türkiye'de okul kütüphanelerinin hizmet vermesini etkileyen faktörleri ele alan bir çalışmada eğitim politikalarının, kalkınma planları gibi yönetsel ilkelerin, teşkilat yapısı ve yönetmeliklerin okul kütüphanelerinin hizmetlerinde belirleyici olduğu dile getirilmiştir (Önal, 1986). Ek olarak konuyla ilgili yönetmelik ve genelgelerdeki derme yönetimi, okul kütüphanelerinin kullanım sürelerinin genişletilmesi, verilmesi planlanan kütüphanecilik dersleri gibi uygulamaların sürdürülebilir bir işleyiş göstermediği de vurgulanmıştır (Önal, 1986; Önal, 1985). Bu konuyla ilgili olarak daha güncel boyutta gerçekleştirilen bir araştırmada ise okul kütüphanelerinin temel işlevinin müfredatı desteklemek olduğu belirtilmiş ancak Türkiye'deki eğitimle ilgili idari düzenlemelerin içeriğinde eğitim ile okul kütüphaneleri arasında bir ilişkinin olmadığı rapor edilmiştir (Aydın, 2004). Bir diğer çalışmada ise okul kütüphanesinin kolay ulaşılabilir bir konumda olması, her okulda bir kütüphanenin bulunması, Millî Eğitim Şûralarının bir bölümünün mutlaka okul kütüphanelerine ayrılması, okul kütüphanecisine ve kütüphaneye yönelik üst yönetim farkındalığı ve desteği gibi konular ele alınmıştır. Çalışmada ayrıca her okul kütüphanesinde kütüphaneci istihdamının gerekliliğine işaret edilerek bu yapılarda bilgi ve belge yönetimi eğitimi almış uzman personelin önemine değinilmiştir (E. Yılmaz, 2015). Okul kütüphanelerinde nitelikli insan kaynağ1 eksikliği, hem okul kütüphanelerine yönelik uygulama analizlerinde hem de organizasyon yapısıyla ilgili çalışmalarda yoğun olarak değinilen bir konu olarak öne çıkmaktadır. Ayrıca literatürde, 
okullarda okul kütüphanecisi seçimine yönelik matematiksel ölçümler öneren çalışmalar da yer almaktadir (M. Yilmaz, 2015).

İş birliği konusu da çalışmalarda incelenen konulardan biridir. Bu kapsamda okul kütüphaneleri ve bilgi gereksinimlerinin karşılanmasını konu alan bir çalışma da okul kütüphaneleri arasında iş birliğinin yetersiz olduğunu ortaya koymuştur (Önal, 1992). Bir diğer çalışmada ise okul kütüphanelerinin halk kütüphaneleriyle iş birliğinde bulunması gerektiği ve mevcut durumda bu iki kütüphane türü arasındaki iş birliğinin düşük düzeyde olduğu ifade edilmiştir (B. Y1lmaz, 1998). Aydın il merkezindeki okul ve halk kütüphanelerini analiz eden başka bir çalışma da 1998 yılında yapılan çalışmaya benzer şekilde iki kurum türü arasındaki iş birliği yetersizliğini ortaya koymuştur (Öçalan, 2010). Bu konuyla bağlantılı olarak 2006 yılında gerçekleştirilen bir yüksek lisans tezinde ise okul kütüphanecileri ile öğretmenler arasındaki iş birliğinin akademik başarıyı olumlu etkilediği savından hareketle İstanbul'daki özel okullara yönelik bir araştırma gerçekleştirilmiştir. Araştırma sonuçlarında söz konusu dönemde İstanbul'daki özel okullarda gelişmiş bir iş birliği çalışmasının olmadığına değinilmiştir (Cevizbaş Akyol, 2006).

\section{Z-Kütüphaneler}

Okul kütüphaneleri bağlamında Millî Eğitim Bakanlığı tarafından yürütülen girişimlerden biri zenginleştirilmiş kütüphaneler olarak adlandırılan "Z-Kütüphane" çalışmasıdır. Teknolojik gelişmelerin Türkiye'de okul kütüphanelerine yansıması olan ve 2011 yılında başlatılan zkütüphane uygulaması ile okullardaki kütüphanelerin hem öğrenciler hem de yetişkinler için "hayat boyu öğrenme merkezi”, eğlenme-dinlenme etkinliklerinin gerçekleştirildiği güvenli alanlara dönüştürülmesi amaçlanmaktadır (Milli Eğitim Bakanlığg, 2015). Bakanlık tarafından oluşturulan z-kütüphane resmi web sayfasında da bu kütüphaneler "estetik ve ergonomik tasarımıyla öğrencilerin okullarda bilgiyi sevme, öğrenme ve dinlenme etkinliklerine imkân veren sosyal etkinlik alanı" olarak tanımlanmaktadır (Z-Kütüphane-Milli Eğitim Bakanlığı, 2019). Z-kütüphanelerle okul kütüphanelerinin fiziki şartlarının, teknolojik altyapılarının geliştirilmesi ile kütüphane hizmetlerinin çağdaş bir yaklaşımla verilmesi hedeflenmektedir (Milli Eğitim Bakanlığı, 2015). Z-kütüphane resmi web sayfasında yer alan verilere göre Türkiye'de 2019 yılı Ekim ayında 1549 z-kütüphane bulunmaktadır ("Milli Eğitim Bakanlığ1 Z-Kütüphane Haritası", 2019).

2014 yılında z-kütüphanelere yönelik bir etki analizi çalışması gerçekleştirilmiştir. Araştırmanın gerçekleştirildiği dönemde Bakanlık verilerine göre 207 okulda bulunması gereken z-kütüphanenin 48 okulda bulunmadığı tespit edilmiştir. Araştırma kapsamında 130 okuldan 2629 öğrenci ve 641 öğretmenin z-kütüphaneye ilişkin yaklaşımları analiz edilmiştir. Sonuçlara göre z-kütüphanelere yönelik en yoğun ilgi ilkokul en az ilgi ise lise düzeyindedir. Araştırma, kütüphane dermelerinin geliştirilmesine olan ihtiyacı yansıtmaktadır. Bu etki analizinde, araştırmanın erken bir araştırma olduğu ve ilerleyen dönemlerde tekrarlanması gerektiği de belirtilmektedir (Milli Eğitim Bakanlığı, 2014).

Gerçekleştirilen bir diğer araştırmada zenginleştirilmiş kütüphanelerin öğrencilerin zihinsel ve kişisel gelişimlerine yönelik etkileri Rize Ahmet Mesut Y1lmaz İlkokulundaki 120 öğrenci üzerinde analiz edilmiştir. Araştırma sonuçları, öğrencilerin büyük çoğunluğunun zenginleştirilmiş kütüphanelerin fiziksel, çevresel ve sosyal koşullarından memnun kaldığını, 
kütüphanelerde gerçekleştirilen sosyal aktivitelerin öğrencilerin kütüphaneye olan ilgi ve taleplerini artırdığını ortaya koymuştur (Ak ve Çetintaş, 2015).

Bir diğer araştırma ise her sınıf seviyesinden z-kütüphaneyi en az bir kere kullanmış olan 80 ortaokul öğrencisi ile gerçekleştirilmiştir. Araştırma sonuçları öğrencilerin kullandıkları z-kütüphanenin fiziksel tasarım olarak rahat bir okuma ortamı sağladığını göstermiştir. Bununla birlikte öğrenciler bu kütüphanelerdeki bilgisayar, masa ve sandalye gibi donanımların yenilenmesi gerektiğini belirtmiştir (Duran ve Ertan Özen, 2018). Buna ek olarak bazı okullardaki donanım altyapısının kaldırıldığı veya bu araçların okullardaki farklı iş süreçleri ve ihtiyaçlar için kullanıldı̆̆ı da görülmektedir (Polat ve Akkaya, 2015).

Ortaokul öğrencilerinin z-kütüphane kullanımlarını araştıran başka bir çalışma, Artvin Atatürk Ortaokulunda gerçekleştirilmiştir. Kütüphanenin açıldığı zamandan itibaren bir yıllık bir süre içerisinde iki haftalık aralıklarla kütüphane ortamının gözlendiği araştırmada kütüphane kuruluşunu izleyen ilk aylarda yoğun bir ilginin olduğu, kütüphanenin çoğunlukla ödünç verme hizmeti için tercih edildiği vurgulanmıştır. Bunun yanı sıra çalışmada z-kütüphanelerin hizmet kalitesinin artırılması için derme geliştirme politikalarına ve uzman kütüphaneci istihdamına ihtiyaç duyulduğu belirtilmiştir (Öztürk ve Tağa, 2018).

Z-kütüphane kullanımı ve z-kütüphaneye yönelik yaklaşımlar okullardaki yöneticiler ve öğretmenler açısından da incelenmiştir. Bu bağlamda bir çalışmada beş okul yöneticisi ve beş öğretmen ile yapılan görüşmelerden elde edilen bulgular paylaşılmıştır. Çalışmada zkütüphanelerin sayılarındaki artışa karşın bu sayının henüz yeterli olmadığı vurgulanmış; bu kütüphanelerin personel politikasının gözden geçirilmesi önerilmiştir (Çakmakkaya, 2017). Literatürde bu konuya farklı kapsamdaki çalışmalarda değinilmiştir (Akman ve Akman, 2017; Aslan, 2017; Durukan, 2015b).

Türkiye'de okul kütüphaneleriyle ilgili literatürde bu kütüphanelerin mekânsal özelliklerini ayrıntılı bir şekilde inceleyen çalışma sayısı oldukça azdır. $\mathrm{Bu}$ durumun oluşmasında devlet okullarının bina tasarımları içerisinde kütüphaneye yer verilmemesi etkilidir. Bunun yanı sıra z-kütüphane yaklaşımıyla okul kütüphanelerinin mekânsal yapılarının oluşturulması için girişimlerde bulunulmaktadır (Küçükkcan, 2015). Mekânsal tasarım aşamasında okul kütüphanelerinde kullanılacak renklerin okuma, öğrenme, eğlenme ve ortak çalışma yapma gibi amaçlara teşvik edecek bir yaklaşımla belirlenmesi önem taşımaktadır (Hashempour ve Taghizadeh Sapchi, 2015).

Genel olarak değerlendirildiğinde Türkiye'de dünyadaki gelişmelere benzer şekilde okul kütüphanelerine yönelik çalışmalar gerçekleştirilmiştir. $\mathrm{Bu}$ doğrultuda okul kütüphanelerindeki uygulamalarla ilgili geliştirme ve iyileştirmelere yönelik ihtiyaçlar da uzun süredir vurgulanmaktadır.

\section{Çalışmanın Amacı, Araştırma Soruları ve Yöntemi}

Önceki bölümlerde sunulan literatür değerlendirmesi ve Türkiye'deki uygulamalar kapsamında çalışmamızda Ankara ili Çankaya ilçesindeki z-kütüphaneye sahip okullardaki mevcut koşullarının ve konuyla ilgili yöneticiler ile sorumlu öğretmenlerin okullarındaki zkütüphanelerin yönetimine yönelik görüşlerinin araştırılması amaçlanmıştır. Bu araştırmanın problem cümlesi ise literatürdeki çalışmalardan hareketle; sosyal öğrenme ortamları olarak kurulan z-kütüphanelerin yönetimi konusunda sorunların yaşanması olarak belirlenmiştir. 
Belirlenen araştırma probleminden hareketle araştırmamız kapsamında okullarda z-kütüphane ile ilgili şu sorulara yanıt aranmıştır:

S1. Z-kütüphanelerin kullanım amaçları ve mevcut mekânsal alan koşulları nedir?

S2. Yöneticilere ya da z-kütüphane sorumlularına göre z-kütüphane yönetimi ile ilgili karşılaşılan sorunlar nelerdir?

S3. Yöneticilere ya da z-kütüphane sorumlularına göre z-kütüphanelerdeki kaynaklardan, teknolojik araç ve gereçlerden nasıl yararlanılmaktadır?

Sunulan amaç ve araştırma soruları doğrultusunda araştırmamız düzey olarak betimsel (descriptive) araştırmadır. Betimsel araştırmalar, verilen bir durumu olabildiğince tam ve dikkatli bir şekilde tanımlamaya yönelik araştırma olarak ifade edilmektedir (Büyüköztürk, Kılıç Çakmak, Akgün, Karadeniz ve Demirel, 2017, s. 24). Araştırmamız temel aldığı felsefe açısından nitel araştırma desenlerinden biri olan durum çalışmasını örneklemektedir. Durum çalışması, güncel bir olgunun kendi gerçekliğinde ele alındığı, nasıl ve ne için sorularına dayanan, araştırmacının kontrol edemediği bir olgu ya da olayın derinlemesine incelenmesini kapsayan bir araştırma yöntemi şeklinde tanımlanmaktadır (Yin, 1984, s. 23; Yıldırım ve Şimşek, 2018, s. 289).

Verilerin toplanmasında yarı yapılandırılmış görüşme ve doğrudan gözlem tekniği kullanılmıştır. Bu bağlamda görüşmelerde kullanılmak üzere z-kütüphane uygulamalarını ve kullanımını betimlemeye yönelik sorulardan oluşan bir form geliştirilmiştir. $\mathrm{Bu}$ formun geliştirilebilmesi için öncelikle dört okuldaki yöneticiler veya kütüphane sorumlusu öğretmenlerle ön görüşmeler gerçekleştirilmiştir. Bu görüşmelerde z-kütüphanelerle ilgili genel durum betimlenerek, diğer okullardaki görüşmelerde kullanılacak formun yapılandırılması sağlanmıştır. Formun geliştirilmesinin ardından Millî Eğitim Bakanlığı z-kütüphane web sayfasındaki z-kütüphane haritasından Çankaya'da 20 okulda z-kütüphane kurulumunun yapıldığ 1 tespit edilmiştir ("Milli Eğitim Bakanlığı Z-Kütüphane Haritası", 2019). Bunlar arasından dört ilkokul, dört ortaokul ve dört lise olmak üzere toplam on iki okul seçilmiş ve bu okullardan veri toplanmıştır. Veri toplanan kütüphaneler Tablo 1'de verilmiştir.

Tablo 1

Veri toplanan okullar

\begin{tabular}{l}
\hline Okul Adı \\
\hline DSİ İlkokulu \\
Gökçe Karataş İlkokulu \\
Hamdullah Suphi İlkokulu \\
Muazzez Karaçay İlkokulu \\
Ahmet Yesevi Ortaokulu \\
Gülen Muharrem Pakoğlu Ortaokulu \\
IMKB Alparslan İmamhatip Ortaokulu \\
Mimar Sinan Ortaokulu \\
Hasan Ali Yücel Sosyal Bilimler Lisesi \\
Ankara Türk Telekom Sosyal Bilimler Lisesi \\
Serçev Engelsiz Mesleki ve Teknik Anadolu Lisesi \\
Hacı Ömer Tarman Anadolu Lisesi \\
\hline
\end{tabular}

Verilerin toplanmasında ilk aşamada okul müdürleri ve müdür yardımcılarıyla telefonla iletişime geçilerek görüşmeler için randevu alınmıştır. Sonrasında ise ilgili okullara gidilerek 
okul müdürleri ve müdür yardımcılarıyla veya araştırma için gerekli olabilecek ayrıntılı bilgi verebilecekleri için okul müdürlerinin yönlendirmeleri sonucunda kütüphaneden sorumlu öğretmenlerle görüşmeler gerçekleştirilmiştir. Bu kapsamda görüşmelerde dört okulda müdürlerle, üç okulda müdür yardımcılarıyla, beş okulda ise ilgili müdür veya müdür yardımcılarının yönlendirmeleriyle kütüphaneden sorumlu olan öğretmenlerle görüşülmüştür. $\mathrm{Bu}$ doğrultuda araştırmada katılımcı grubu 12 kişiden oluşmaktadır. Görüşme yapılan öğretmenlerin tamamı Türkçe ya da Edebiyat öğretmenleridir. 2019 yılı Nisan ayı içerisinde gerçekleştirilen görüşmelerin her biri yaklaşık bir saat otuz dakika sürmüştür. Görüşmelerde toplanan her veri önceden hazırlanmış olan görüşme formuna kaydedilmiştir. Bunun yanı sıra okulların öğrenci ve sınıf sayıları ile ilgili kütüphanelerin alanı ve sahip olunan bilgisayar sayısı da okulların web sayfalarından toplanmıştır. Derlenen bilgilere ek olarak öğrenci sayıları derslik sayılarına bölünerek tahmini olarak bir derslikteki öğrenci sayıları belirlenmiştir. zkütüphane alanının bir derslikteki tahmini öğrenci sayısına bölünmesiyle de kütüphanelerin bir sınıf tarafından topluca kullanımı sırasında öğrenci başına düşebilecek alanlar hesaplanmıştır.

Doğrudan gözlem yönteminden de yapılan görüşmelerden elde edilen verileri doğrulamaya yönelik olarak kütüphanelerdeki bilgisayarların kullanılabilir durumda olup olmadığı, kütüphanenin açık tutulup tutulmadığı gibi verilerin toplanmasında faydalanılmıştır. Araştırma, veri toplama tekniklerine göre görüşmelere dayalı olarak toplanan verilerin analizini temel alan görgül bir araştırma niteliği taşımaktadır. Bunun yanı sıra araştırmada hem görüşmelerden elde edilen veriler, hem de başka amaca yönelik olarak okul kütüphanelerine ilişkin web sayfalarında ve z-kütüphanelere ait otomasyon sisteminde sunulan veriler analiz edilmiştir. Bu doğrultuda araştırmada hem birincil hem de ikincil veriler ${ }^{1}$ kullanılmıştır.

\section{Bulgular}

Araştırma kapsamında ilk olarak okullarda z-kütüphane kurulumundan önce bir kütüphanenin bulunup bulunmadığı ele alınmıştır. Bu çerçevede dokuz okulda z-kütüphane kurulumundan önce de bir kütüphanenin bulunduğu tespit edilmiştir. Söz konusu bulguları dokuz okulda kütüphaneye yönelik bir farkındalığın önceden de olduğu, üç okulda z-kütüphane projesi ile kütüphane farkındalığının kazandırıldığı şeklinde yorumlamak mümkündür. İncelenen bir okulda z-kütüphane kurulumunun dışında yaratıcı kütüphane adıyla bir kütüphanenin kurulduğu ve okulda iki kütüphanenin bulunduğu ifade edilmiştir. Bir okulda ise dersliğin zkütüphaneye dönüştürüldüğü bilgisi edinilmiştir.

Araştırmada okullardaki z-kütüphanelerin mekânsal özelliklerine, okullardaki öğrenci ve sınıf sayılarına ilişkin bulgular da elde edilmiştir. Okulların web sayfaları ve Milli Eğitim Bakanlığı z-kütüphane web sayfasından edinilen bilgiler Tablo 2'de derlenmiştir.

\footnotetext{
${ }^{1}$ Birincil veriye dayanan araştırmalar; araştırmaların sınıflandırılmasında toplanan verilerin niteliği açısından yapılan sınıflandırmalar içerisinde yer alan türlerden biridir. Bu araştırmalarda ihtiyaç duyulan veri yalnızca araştırma amaçları için toplanır. İkincil veriye dayanan araştırmalarda ise veriler daha önce başka amaçlar için derlenmiş ve kayıt altına alınmıştır (Büyüköztürk ve diğerleri, 2017, s.13).
} 
Tablo 2

İncelenen okullardaki z-kütüphaneye, ögrenci sayllarına ve dersliklere ilişkin bulgular

\begin{tabular}{lrrrrrr}
\hline Okul & Alan $\left(\mathrm{m}^{2}\right)$ & $\begin{array}{r}\text { Yapım } \\
\text { yılı }\end{array}$ & $\begin{array}{r}\text { Öğrenci } \\
\text { sayıs1 }\end{array}$ & $\begin{array}{r}\text { Derslik } \\
\text { sayıs1 }\end{array}$ & $\begin{array}{r}\text { Bir derslikteki } \\
\text { öğrenci sayıs1 }\end{array}$ & $\begin{array}{r}\text { Öğrenci başına } \\
\text { düşen alan }\left(\mathrm{m}^{2}\right)\end{array}$ \\
\hline İ1 & 64 & 2015 & 370 & 13 & 23 & 2,8 \\
$\dot{\text { İ2 }}$ & 92 & 2017 & 551 & 24 & 23 & 4,0 \\
İ3 & 80 & 2016 & 534 & 29 & 22 & 4,4 \\
$\dot{\text { I4 }}$ & 80 & 2018 & 703 & 32 & 32 & 3,6 \\
O1 & 70 & 2015 & 536 & 17 & 38 & 2,2 \\
O2 & 120 & 2015 & 1349 & 36 & 17 & 3,2 \\
O3 & 104 & 2015 & 539 & 31 & 20 & 6,2 \\
O4 & 98 & 2015 & 312 & 16 & 21 & 4,9 \\
L1 & 80 & 2015 & 507 & 24 & 24 & 3,8 \\
L2 & 150 & 2015 & 552 & 23 & 9 & 6,3 \\
L3 & 73 & 2018 & 238 & 29 & 26 & 8,0 \\
L4 & 120 & 2015 & 702 & 27 & 4,6 \\
\hline
\end{tabular}

Tablo 2'de sunulan veriler z-kütüphanelerin alan olarak $64 \mathrm{~m}^{2}$ ile $150 \mathrm{~m}^{2}$ arasında olduğunu göstermektedir. Tablo 2'ye göre okullardaki sınıfların ortalama mevcutları 9 ile 38 arasındadır. Bu noktada alanı $70 \mathrm{~m}^{2}$ olan kütüphaneden 32 kişilik bir sınıfın ders kapsamında yararlanması durumunda kişi başına $2,2 \mathrm{~m}^{2}$ düşmektedir. Benzer şekilde $64 \mathrm{~m}^{2}$ olan kütüphaneden 23 öğrencinin yararlanması durumunda kişi başına düşen alan 2,8 $\mathrm{m}^{2}$ 'dir. Ortalama olarak bir derslikteki öğrenci sayısı temel alınarak yapılan hesaplamalara göre kişi başına düşen alan 2,2 $\mathrm{m}^{2}$ ile $6,3 \mathrm{~m}^{2}$ arasında değişim göstermektedir. Z-kütüphane alanlarının okul türlerine göre dağılımı Şekil 1'de kutu grafiği ile verilmiştir.

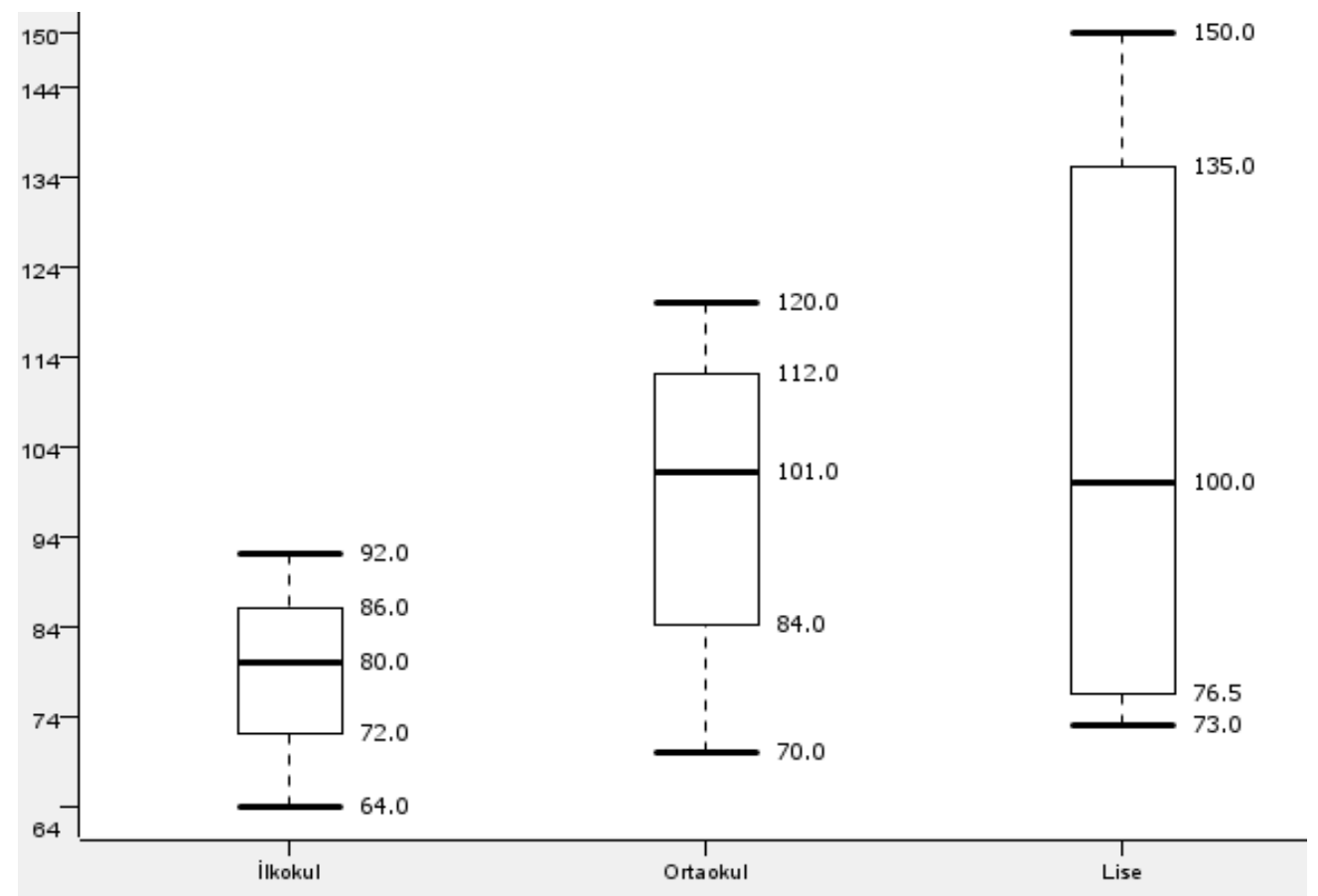

Şekil 2. Okul türüne göre z-kütüphane alanları

Şekil 2'ye göre ilkokullardaki z-kütüphaneler alan olarak ortaokul ve lisedeki zkütüphanelerden daha küçüktür. İlkokullardaki z-kütüphanelerin alanı ortalama olarak $80 \mathrm{~m}^{2}$ olup, bu okullardaki z-kütüphanelerin en genişi $92 \mathrm{~m}^{2}$ 'lik bir alana sahiptir. Ortaokullardaki 
kütüphanelerin alanları ise $70 \mathrm{~m}^{2}$ ile $120 \mathrm{~m}^{2}$ arasında değişmektedir. Bu okullarda ortalama 101 $\mathrm{m}^{2}$ 'lik bir alan z-kütüphane için ayrılmıştır. Liselerdeki kütüphane alanları diğer iki okul türüne göre daha geniştir. Bu bağlamda liseler için z-kütüphane alanları $73 \mathrm{~m}^{2}$ ile $150 \mathrm{~m}^{2}$ arasındadır. Söz konusu bulgularla ilgili olarak Küçükcan'ın (2015) Neufert’ten (2000) aktarımına göre ilkokuldaki kütüphanelerin genel alan olarak 60-65 m², ortaokullardaki kütüphanelerin 60-75 $\mathrm{m}^{2}$ ve liselerdeki kütüphanelerin 70-75 $\mathrm{m}^{2}$ olması gereklidir. Küçükcan (2015, s. 228) aynı çalışmada bu oranların Türkiye'deki okul kütüphaneleri için minimum değerler olarak görülmesi gerektiğinin altını çizmektedir. Bu çerçevede analiz edilen kütüphanelerin alanları belirtilen çalışmadaki alanlarla örtüşmektedir. Diğer yandan raf, mobilya ve masa gibi düzenlemelerle kütüphanelerin kullanım alanlarının dikkate değer bir düzeyde düşüş göstereceğinin de göz önünde bulundurulması gerekmektedir.

Araştırmada ilgili okullardaki z-kütüphanelerde görevli olan bir personelin bulunup bulunmadığına ilişkin bulgular da elde edilmiştir. Buna göre araştırmadaki okulların yalnızca ikisinde kütüphanede görevlendirilmiş bir görevli bulunmaktadır. Diğer on okuldaki zkütüphane ise öğretmenlerin, öğrenci kulüplerinin ve nöbetçi öğrenci olarak görevlendirilen öğrencilerin sorumluluğunda yönetilmektedir. Görüşmelerde z-kütüphanede görevli bulunan okullardaki bu görevlilerin kütüphanecilik ve bilgi bilim alanıyla ilgili bir uzmanlı̆̆ının olmadığı ifade edilmiştir. Okullardan yalnızca birinde daha önceden uluslararası bir programa uyum süreci kapsamında bilgi ve belge yönetimi alanından bir uzman görev yapmıştır. Bunun yanı sıra bir kütüphanede ise Türkiye İş Kurumundan (İş-Kur) bir kişinin kısa bir süre istihdam edildiği ancak bu süreçten okul yönetiminin istenen verimi alamadığı dile getirilmiştir. Ulusal literatürdeki birçok çalışmada okul kütüphanelerinde Bilgi ve Belge Yönetimi Bölümü mezunlarının istihdamına yönelik ihtiyaçlara değinilmektedir (Öztürk ve Tağa, 2018; Ak ve Çetintaş, 2015; E.Yılmaz, 2015).

Okul yöneticilerine ve z-kütüphanelerden sorumlu öğretmenlere yöneltilen sorulardan biri de z-kütüphanelerin kullanımına yöneliktir. Söz konusu soruya verilen cevaplar çerçevesinde elde edilen bulgular Tablo 3 'te sunulmuştur.

Tablo 3

Z-kütüphanenin kullanım şekli

\begin{tabular}{|c|c|c|c|c|c|c|c|c|c|c|c|c|}
\hline Kullanım şekli & İ1 & İ2 & İ3 & İ4 & O1 & $\mathrm{O} 2$ & $\mathrm{O} 3$ & $\mathrm{O} 4$ & L1 & L2 & L3 & L4 \\
\hline Ders Çalışma & & & & & $\checkmark$ & $\checkmark$ & & $\checkmark$ & $\checkmark$ & $\checkmark$ & $\checkmark$ & $\checkmark$ \\
\hline Okuma Saati / Ders & $\checkmark$ & $\checkmark$ & $\checkmark$ & $\checkmark$ & $\checkmark$ & $\checkmark$ & $\checkmark$ & $\checkmark$ & & & & \\
\hline $\begin{array}{l}\text { Yazar Söyleşisi, Seminer / } \\
\text { Konferans }\end{array}$ & & & $\checkmark$ & & $\checkmark$ & & & & & & & $\checkmark$ \\
\hline İnternet erişimi & & & & & $\checkmark$ & & & & & $\checkmark$ & & $\checkmark$ \\
\hline Öğrenci kulübü çalışmaları & & & & & & & $\checkmark$ & $\checkmark$ & & & $\checkmark$ & \\
\hline
\end{tabular}

Tablo 3'te verilen bulgular beş okulda z-kütüphanenin çoğunlukla ders çalışma amacıyla kullandığını ortaya koymaktadır. Sekiz okul okuma saati gibi dersler kapsamında zkütüphaneyi kullanmaktadır. Üç okulda ise z-kütüphanede yazar söyleşisi, seminer ve konferans gibi etkinlikler düzenlenmiştir. Bulgulara göre okullardaki kütüphaneler toplu bir 
şekilde ya da bir ders kapsamında da kullanılmaktadır. Bu noktada özellikle lise türünde ders çalışma amacıyla kullanım öne çıkarken ilk ve ortaokullarda okuma saati uygulamaları yoğunluk göstermiştir. Toplu kullanımlarda Tablo 2'deki bulgular dikkate alındığında bazı kütüphaneler için öğrenci başına düşen alanın $\mathrm{m}^{2}$ bazında oldukça sınırlı olduğunu söylemek mümkündür. Üç okuldaki z-kütüphanede öğrenciler internet erişiminden faydalanabilmektedir. Buna ek olarak görüşmelerin yapıldığı dönemde sekiz okuldaki z-kütüphanenin kilitli olarak tutulduğu, dört okulda ise okulun açık olduğu saatlerde z-kütüphanenin de açık tutulduğu tespit edilmiştir.

Araştırmada yöneticilere ve öğretmenlere okullarındaki z-kütüphanelerdeki bilgi kaynaklarının ödünç olarak öğrencilere kullandırılmasıyla ilgili bir soru yöneltilmiştir. Bu çerçevede yedi okuldaki z-kütüphanede ödünç verme işleminin yapılmadığı, kaynakların yalnızca kütüphane içerisinde kullanıma sunulduğuna ilişkin yanıtlar alınmıştır. Ödünç verme işleminin yapıldığı okullarda ise bu işlemlerin kütüphanede oluşturulan kayıt defterine işlenerek gerçekleştirildiği belirlenmiştir. Bir kütüphanede ise ödünç işlemlerinde denetimin sağlanması konusunda sorunların yaşandığı anlaşılmıştır. Ayrıca daha önce bir uzman kütüphanecinin görev yaptığı okuldaki z-kütüphanede, ilgili dönemde Ankara'daki z-kütüphaneye sahip okullar arasında en fazla ödünç verme işleminin yapıldığı ifade edilmiştir. Bir okuldaki kitapların ve kütüphanenin tanıtımına yönelik bir el afişi çalışmasının yapılarak öğrencilere ve velilerine ulaştırılmasının hedeflendiği dile getirilmiştir.

Okullardaki z-kütüphanelerdeki görüşmelerde koleksiyonla ilgili bulgular da elde edilmiştir. Buna göre yedi okuldaki yöneticiler ve öğretmenler mevcut koleksiyonu okuldaki öğrenciler için yeterli görmemektedir. Beş okuldaki z-kütüphane koleksiyonu ise yönetici ve öğretmenlere göre yeterli düzeydedir. Bir okulda projeler aracılığıyla süreli yayın aboneliğinin olduğu anlaşılmıştır. Görüşmelerde iki okul ise bir halk kütüphanesi ile iş birliği yaparak koleksiyonuna yeni bilgi kaynaklarının sağlandığını ve yıpranan kaynakların tadilatlarının gerçekleştirildiğini ifade etmiştir. Bir okulda ise koleksiyona bağış yoluyla yeni kaynaklar temin edilmiştir. Bu yolla sağlanan kaynakların çoğunluğunun aynı kaynak olmasından ve kaynakların konu çeşitliliği açısından sınırlılık göstermesinden dolayı koleksiyonun istenen düzeyde olmadığı belirtilmiştir. Analizlerin gerçekleştirildiği okullarda bir koleksiyon geliştirme politikası bulunmamaktadır.

Z-kütüphanelerde masaüstü bilgisayar ve akıllı tahta gibi araçların bulunduğu bilinmektedir. $\mathrm{Bu}$ kapsamda analiz edilen okulların yalnızca üçünde bilgisayarların ve internetin aktif bir şekilde kullanıldığı görülmüştür. Bu okullardaki projelerin ve kütüphaneden sorumlu olan öğretmenin çabalarının bu tür araçların kullanımında önemli ölçüde etkili olduğu görüşmelerde dile getirilen bir nokta olmuştur. Dokuz okuldaki z-kütüphanede masaüstü bilgisayar ve internetin öğrenciler tarafından aktif bir şekilde kullanılmadığı belirtilmiştir. $\mathrm{Bu}$ konuyla ilgili olarak literatürde z-kütüphanedeki bilgisayarların öğrenciler tarafından çok yoğun bir şekilde kullanıldığını vurgulayan çalışmalar olduğu gibi bilgisayarların bozulduğu ya da kullanılmadığı için kütüphanelerden kaldırıldığını raporlayan çalışmalar da bulunmaktadır (Öztürk ve Tağa, 2018; Duran ve Ertan Özen, 2018; Polat ve Akkaya, 2015). Araştırmamızda elde edilen bulgular her iki durumu da betimlemektedir. Bu çerçevede bilgisayar ve diğer teknoloji araçlarının okullardaki kullanımlarının farklılık gösterdiği söylenebilir. 
Z-kütüphane kurulum sürecinde okullara web tabanlı bir otomasyon sistemi sağlanmakta ve kütüphanelerin koleksiyonlarını bilgi ve belge yönetimi alanındaki uluslararası standartlara uygun bir yapıya sahip olan bu sistemde tanımlamaları beklenmektedir. Araştırmada incelenen okulların yalnızca birinin web sayfasında bu sisteme yönelik bir yönlendirme ve kullanım dokümanı bulunmaktadır. Okullardan ilgili otomasyon sisteminde (http://kutuphanem.meb.gov.tr/) tanımlanan bilgi kaynağı sayıları Tablo 4 'te verilmiştir.

Tablo 4

\begin{tabular}{lr}
\multicolumn{2}{c}{ Otomasyon sisteminde tanimlanan kaynak saylsl } \\
\hline Okul & Otomasyon sistemindeki kayit sayıları \\
\hline İ1 & 511 \\
İ2 & 354 \\
İ3 & 0 \\
İ4 & 0 \\
O1 & 910 \\
O2 & 598 \\
O3 & 0 \\
O4 & 742 \\
L1 & 96 \\
L2 & 10027 \\
L3 & 0 \\
L4 & 847 \\
\hline
\end{tabular}

Tablo 4'te verilen bilgiler doğrultusunda bazı z-kütüphanelerdeki bilgi kaynaklarının katalog kayıtlarının otomasyon sisteminde oluşturulmadığı görülmektedir. Bir z-kütüphanede tanımlanan kaynak sayısı 96'dır. Bu durum otomasyon sisteminin beş z-kütüphanede aktif olarak kullanılmadığını yansıtan bir bulgu olarak değerlendirilebilir. Bir okuldaki zkütüphaneden otomasyon sistemine 10.000 'in üzerinde kayıt girildiği de dikkati çekmektedir. $\mathrm{Bu}$ sayının nedeni, ilgili okulda daha önce kütüphanecilik alanındaki uzman bir personelin görevlendirilmesiyle birlikte kaynakların bibliyografik kayıtlarının sistemde oluşturulması olarak gösterilmektedir. Diğer yandan yöneticiler ve öğretmenlerle yapılan görüşmelerde yedi okuldaki z-kütüphanede otomasyon sisteminin kullanılmadığı, iki okulda ise bu sistemin yetkililer tarafından kullanıldığı ortaya çıkmıştır. Bir okulda z-kütüphane otomasyon sisteminin kurulumundan önce web tabanlı bir başka sistemde bilgi kaynaklarının tanımlandığı ve bu süreç için bir halk kütüphanesinden yardım alındığı dile getirilmiştir.

Araştırmada son olarak katılımcıların z-kütüphanelerde karşılaştıkları sorunların neler olduğunu açıklamaları istenmiştir. Verilen yanıtlar benzerliklerine göre gruplandırılmıştır. $\mathrm{Bu}$ bağlamda analizlerin gerçekleştirildiği 12 okulda karşılaşılan sorunları genel olarak aşağıdaki gibi sunmak mümkündür:

- Z-kütüphanenin kurulum aşamasının uzun sürmesi,

- Otomasyon sistemindeki yetkilendirmelerin geç yapılması,

- Yüksek öğrenci sayısı nedeniyle toplu etkinliklerin gerçekleştirilememesi,

- Uzman personel ihtiyac1,

- Öğretmenlerin iş yükleri nedeniyle kütüphanenin etkin bir yönetiminin olmaması,

- Geleneksel kütüphanecilik hizmetlerine yönelik sorunlar,

- Ödünç verme uygulamalarında denetim sorunları, 
- Koleksiyon geliştirme politikası gibi süreçlerde karar verme sorunları,

- Kütüphane alanına ilişkin yetersizlikler,

- Bütçe problemleri.

Buna göre z-kütüphanelerde karşılaşılan sorunların, genellikle kütüphane hizmetlerinin sürdürülebilirliğinin sağlanamamasına yönelik olduğu anlaşılmaktadır.

\section{Sonuç ve Öneriler}

Okul kütüphaneleri, bireylerin aldıkları temel eğitim sürecinde önemli bir yeri olan kütüphane türlerindendir. Okul içerisinde bilgi hizmetlerinin sunulmasında öne çıkan aktörlerden biri olan okul kütüphaneleri, hizmet verdiği kitle bakımından bilgi iletişim ve teknolojiye yönelik güncellemelere en yoğun ihtiyaç duyan yapılardan biridir. Bu noktada okul kütüphanelerinin başta teknik altyapı olmak üzere birçok konuda yeniliklerde bulunarak hizmet verdiği kitlenin bilgi ile olan etkileşimlerini artırmaya yönelik çalışmalar gerçekleştirilmektedir. Literatürde de okul kütüphaneleri kapsamında koleksiyon geliştirme, bilgi okuryazarlığı, kullanıcı araştırmaları, kütüphane eğitimi, üniversite ve halk kütüphaneleriyle iş birliği, sosyal medya ve internet gibi konulara değinilmektedir. Diğer ülkelerde olduğu gibi Türkiye'de de okul kütüphanelerine yönelik konular ve karşılaşılan sorunlar çok yönlü olarak ele alınmakta, okul kütüphanelerinin geliştirilmesi bağlamında girişimlerde bulunulmaktadır. Bu girişimlerden biri olan z-kütüphane projesi Millî Eğitim Bakanlığı tarafından yürütülmektedir. Okullardaki kütüphanelerin birer sosyal öğrenme ortamına dönüşümünü hedefleyen proje 2014 yılında başlamıştır. Proje kapsamında Türkiye genelinde z-kütüphaneye sahip okul sayısı 2014 yılında 56 iken, 2019 yılı Ekim ayı itibariyle bu sayı 1549'a ulaşmıştır. Bu artış okullarda kütüphaneye yönelik yatırımların artış gösterdiğini yansıtan bir durum olarak yorumlanabilir.

Bu çalışmada Ankara'nın Çankaya ilçesinde yer alan okullardaki z-kütüphanelerin mevcut koşullarının ve hizmet olarak sunulan olanaklarının betimlenmesi amaçlanmıştır. $\mathrm{Bu}$ amaç çerçevesinde z-kütüphane ile okullarda sunulan sosyal öğrenme ortamının yönetimine ilişkin karar verici ya da verilen kararı uygulayıcı pozisyonunda bulunan yönetici ve zkütüphaneden sorumlu öğretmenlerle görüşmeler gerçekleştirilmiştir. Araştırmada ayrıca ziyaret edilen z-kütüphanelere ilişkin mekân verileri ve bibliyografik kayıt verileri için okul ve z-kütüphane web sayfası ile ilgili otomasyon sistemi kullanılmıştır. Sunulan bulgular çerçevesinde sonuçlar değerlendirildiğinde araştırmadaki okulların üçünde daha önceden planlanmış bir kütüphane alanının olmadığı dikkati çekmektedir. Bunun yanı sıra bir dersliğin z-kütüphaneye dönüştürülmesi ilgili okul binasına ve bina planına, bir başka deyişle mekân tasarımına yönelik eksiklikleri ortaya koymaktadır. Okul türü açısından kütüphane alanlarına yönelik bulgular ilk ve ortaokullardaki z-kütüphanelerin alanlarının liselerdeki z-kütüphanelere göre nispeten daha küçük olduğunu yansıtsa da okul bazında kütüphane alanları farklılık gösterebilmektedir. Analizlerin gerçekleştirildiği okullardaki z-kütüphanelerin alanları ilkokul, ortaokul ve lise için belirtilen standart kütüphane alanlarıyla uyumluluk göstermektedir. Ancak standartlarda belirtilen alan ölçülerine uygun olsa dahi dersliklerdeki öğrenci sayısı fazlalığ1 nedeniyle z-kütüphanenin toplu bir şekilde kullanımı ile ilgili sorunlarla karşılaşılabilmektedir. Burada öğrenci sayılarının ve kütüphane iç dekorasyonunun önemli birer etken olduğunun göz önüne alınması gerekmektedir. 
Analiz edilen z-kütüphanelerin kullanımlarına yönelik bulgular ilkokul ve ortaokulda okuma saatleri kapsamındaki kullanımın yoğunluk gösterdiğini, lise düzeyinde ise ders çalışma amaçlı kullanımın öne çıktığını göstermiştir. Burada özellikle sınavlara hazırlık amacıyla öğrencilerin kütüphaneyi kullandıkları yönetici ve öğretmenler tarafından dile getirilmiştir. Diğer taraftan üçer okulda seminerler, konferanslar, yazar söyleşileri ve internet erişimi gibi kullanım amaçlarının da olduğu görülmektedir. İlk araştırma sorusuyla (S1) da bağlantılı olan bu konuda ilgili okullardaki yönetici ve öğretmenlerin konuya yönelik farkındalığının, okuldaki projeler ve uluslararası programlara uyumluluk çalışmalarının kütüphanelerdeki etkinlik çeşitliliğinde etkili olduğu düşünülmektedir.

Araştırmada analiz edilen z-kütüphanelerin önemli bir bölümünün bir uzman personel olmadan yönetildiği sonucuna ulaşılmıştır. Daha önceki birçok çalışmada da değinilen bu sonuç, z-kütüphanenin sürdürülebilirliği ile yakından ilgili bir konu olarak değerlendirilmektedir. İncelenen z-kütüphanelerde çoğunlukla öğretmenler, nöbetçi öğrenciler ve öğrenci kulüpleri görev almaktadır. Bu kapsamda kütüphanenin genel yönetimi ile ilgili süreçlerde de (örneğin katalog kaydı oluşturma, ödünç verme işlemleri gibi) bu kişilerin görev yapması beklenmektedir. Ancak görevli öğretmenlerin haftalık ders yükleri ve söz konusu süreçlerde bilgi ve belge yönetimi alanı uzmanlığına yönelik gereksinimler belirtilen süreçlerin tamamlanamamasına neden olabilmektedir. Z-kütüphanelere sağlanan otomasyon sistemindeki kayıt sayıları da bu durumu doğrular niteliktedir. Z-kütüphanelerdeki ödünç verme işlemleri de personel eksikliği ile ilişkilendirilebilecek bir sorun olarak görülebilir. Otomasyon sisteminden gerçekleştirilebilecek bir işlem olan ödünç verme işlemleri birçok okulda yapılamamakta ve bilgi kaynakları yalnızca z-kütüphane içerisinde kullanıma sunulmaktadır. Ödünç verme işleminin yapıldığı z-kütüphanelerde ise kayıt defterleri kullanılmaktadır. Bu noktada otomasyon sisteminin özelliklerine yönelik farkındalığın oluşturulması gerekmektedir. Sadece bir kütüphanenin web sayfasında otomasyon sistemine bir yönlendirme ve yardım dokümanı bulunmaktadır. Analiz sonuçları z-kütüphanelerdeki bilgisayar ve diğer teknik olanakların kullanımında da okullar arasında farklılık olduğunu ortaya koymuştur. Özellikle üç okulda internet erişimi aktif olarak kullanılırken, dokuz okulda bu olanakların kullanılmadığı, bir okulda da z-kütüphanede bulunan projektör ve sunum perdesinin kütüphanede düzenlenen seminerlerde kullanıldığ 1 belirtilmiştir. Bir okulda ise bilgisayarların bozulduğu ve güncellenmesine ihtiyaç duyulduğu anlaşılmıştır. İkinci araştırma sorusu (S2) ile bağlantılı olan bu konu ile otomasyon sistemine yönelik sonuçlar z-kütüphanede yapılandırılan bu araçların sürdürülebilirliğine yönelik ihtiyaçları yansıtmaktadır.

Araştırmadaki üçüncü soru (S3) ile ilgili sonuçlar incelenen okulların z-kütüphanelerin kurulum aşamasından itibaren çeşitli sorunlarla karşılaştıklarını ortaya koymuştur. Uzman personel ve farkındalık eksikliği, hizmet tasarımına yönelik sorunlar, teknik sorunlar, kütüphane kullanımı ve bütçe ile ilgili sorunlar, geleneksel bilgi ve belge yönetimi uygulamalarına yönelik ihtiyaçlar gibi sorunların ortak noktasının z-kütüphanenin yönetimine ve sürdürülebilirliğinin sağlanmasına yönelik olduğu görülmektedir. Nitekim bir dönem bilgi ve belge yönetimi alanından bir uzmanı istihdam eden okulun z-kütüphanesinde daha sonra kaynakların denetimine yönelik sorunların yaşanması, alan uzmanlarına yalnızca kurulum ve başlangıç aşamasında değil, bu kütüphanelerin sürdürülebilirliği için de ihtiyaç olduğunu göstermektedir. Bir okuldaki yetkililer ise otomasyon sistemindeki yetkilendirme süreçlerinin 
uzun zaman aldığını ifade etmiştir. Yetkililer bu durum karşısında çözüm olarak açık kaynak kodlu ve ücretsiz hizmet sunan web tabanlı başka bir platformda bilgi kaynaklarını katalogladıklarını dile getirmiştir. Bulgularda dokuz okuldaki yönetici ve öğretmen zkütüphaneyi sosyal öğrenme ortamına dönüştürecek bir hizmet geliştirme ya da tasarlama sürecinden söz etmemiştir. Bu durum ilgili yönetici ve öğretmenlerin konuya yaklaşımlarını göstermekle birlikte z-kütüphanenin kurulum amacının yerine getirilmesinde önemli bir unsur olarak değerlendirilmektedir. Konuyla ilgili olarak okullardaki z-kütüphaneleri sosyal öğrenme ortamı olarak güçlendirecek yenilikçi hizmetlerin geliştirilmesine ve bu konuya yönelik yönlendirmelere ihtiyaç bulunmaktadır.

Son olarak araştırmada on iki okuldaki z-kütüphanede yapılan analizler çerçevesinde okullarda farklı sorunların yaşandığı ve bu sorunların z-kütüphanelerin kurulumu odağında değil, sürdürülebilirliğiyle ilgili olduğu anlaşılmaktadır. Z-kütüphane projesinin hayata geçirildiği 2014 yılından itibaren z-kütüphanelerle ilgili etki değerlendirme çalışmalarının sayısının sınırlılığı bu ve sonrasında yapılacak benzer çalışmalar için temel gerekçe niteliği taşımaktadır.

\section{Kaynakça}

Ahlfeld, K. (2019). On the field, not in the stands: shared foundation VI: Engage in the national school library standards for learners, school librarians, and school libraries. Journal of Library Administration, 59(6), 673-683. doi:10.1080/01930826.2019.1626645

Aisah, M. A., Abrizah, A., Aspura, M. K. I. Y. I. ve Dollah, W. A. K. W. (2018). Development of an information literate school community: Perceived roles and practices of teacher librarians. Malaysian Journal of Library \& Information Science, 23(2), 63-75. doi: $10.22452 /$ mjlis.vol23no2.4

Ak, Ş. ve Çetintaş, B. (2015). Eğitimde zenginleşmiş kütüphanelerin yeri ve önemi: Ahmet Mesut İlkokulu zenginleştirilmiş kütüphane uygulaması. Milli Ĕgitim Dergisi, 45(208), 18-32.

Akbulut Güneş, A. (2013). Türkiye'de köy ilköğretim okul kütüphaneleri ve okuma alışkanlığı: Kastamonu örneği (Yayımlanmamş yüksek lisans tezi). Ankara Üniversitesi, Ankara. Erişim adresi: http://bbytezarsivi.hacettepe.edu.tr/jspui/handle/2062/400

Akman, İ. ve Akman, N. (2017). Çocuk ve gençlerde okuma alışkanlığı sorunu: Okul kütüphanelerinin işlevselliğine bir bakış. Türk Kütüphaneciliği, 31(2), 281-285.

Arıcan, S. ve Yılmaz, B. (2010). 100 Temel Eser uygulamasının öğrencilerin okuma alışkanlıklarına etkisi ve bu uygulamada kütüphanelerin rolü konusunda öğretmen görüşleri. Türk Kütüphaneciliği, 24(3), 495-518.

Aslan, C. (2017). Toplam kalite yönetimi perspektifinde eğitim ve okul kütüphanelerinin organizasyonu üzerine bir inceleme. Türk Kütüphaneciliği, 31(2), 251-258. doi:10.24146/tkd.2017.13

Aşıcı, M. ve Özarslan, H. (2002). İlköğretim 1. kademede okul kitaplığını kullanma alışkanlığı. M.Ü. Atatürk Ĕ̈itim Fakültesi Ĕ̈itim Bilimleri Dergisi, 15, 45-56.

Aydın, A. (2004). Okul kütüphanesinin çağdaş eğitime katkısı ve yasal dayanaklar açısından Türkiye'de durum (Yayımlanmamış yüksek lisans tezi). İstanbul Üniversitesi, İstanbul. Erişim adresi: http://bbytezarsivi.hacettepe.edu.tr/jspui/handle/2062/447

Baji, F., Bigdeli, Z., Parsa, A. ve Haeusler, C. (2018). Developing information literacy skills of the 6th grade students using the Big 6 model. Malaysian Journal of Library \& Information Science, 23(1), 1-15. doi:10.22452/mjlis.vol23no1.1 
Baker, D. M., Smith, D., Shea, M. ve Wu, W.-N. (2014). Collaborative resource sharing between public and school libraries. Interlending \& Document Supply, 42(4), 159-164. doi:10.1108/ILDS-092014-0045

Brissett, M. M. (2011). Characters of color: A content analysis of picture books in a Virgin Islands Elementary School Library. New Trends in Qualitative and Quantitative Methods in Libraries içinde (s. 213-217). Singapur: World Scientific. doi:10.1142/9789814350303_0027

Brown, C. A. ve Hill, J. (2009). Connecting media specialists, students, and standards through web 2.0. M. Orey, V. J. McClendon ve R. M. Branch (Ed.), Educational Media and Technology Yearbook içinde (s. 211-229). Boston, MA: Springer US. doi:10.1007/978-0-387-09675-9_15

Büyüköztürk, Ş., Kılıç Çakmak, E., Akgün, Ö. E., Karadeniz, Ş. ve Demirel, F. (2017). Bilimsel araştırma yöntemleri (23. bs.). Ankara: Pegem Akademi Yayıncılık. doi:10.14527/9789944919289

Cevizbaş Akyol, S. (2006). Okul kütüphanecisi ile öğretmen arasındaki işbirliğinin özellikleri (Yayımlanmamış yüksek lisans tezi). İstanbul Üniversitesi, İstanbul. Erişim adresi: http://bbytezarsivi.hacettepe.edu.tr/jspui/handle/2062/457

Cevizbaş, S. (2003). Türkiye'de özel okul kütüphanelerinin sorunları: Özel okul kütüphanelerine yönelik bir anket. Türk Kütüphaneciliği, 17(4), 386-396.

Chu, W. (2013). Library exposure from the prior years: An examination of public high school library websites. The Journal of Academic Librarianship, 39(5), 392-400. doi:10.1016/j.acalib.2013.03.003

Clyde, L. A. (2004). School library Web sites: 1996-2002. The Electronic Library, 22(2), 158-167. doi:10.1108/02640470410533425

Çakmak, T. ve Önal, H. İ. (2013). Bilgi okuryazarlı̆̆ı becerilerinin kazandırılmasında okul kütüphanecilerinin rolleri ve algıları. Türk Kütüphaneciliği, 27(4), 633-647.

Çakmakkaya, İ. (2017). Okul kütüphanelerinde ve eğitim sürecinde dijital olanaklar. Eğitim Bilim Toplum Dergisi, 15(57), 106-118.

Dawkins, A. M. ve Gavigan, K. W. (2017). The School librarian's role in writing instruction: research, perceptions, and practice. Libri, 67(4), 299-312. doi:10.1515/libri-2017-0034

Debus-López, K., McCroskey, M., Reynolds, R. R., Saccucci, C., Williams, C. ve Zwierski, M. (2017). Transforming the CIP data block: Assessing user needs to re-envision a venerable library icon. $\begin{array}{llll}\text { Cataloging \& Classification } \quad \text { Quarterly, 55(7-8), } & \text { 522-548. }\end{array}$ doi:10.1080/01639374.2017.1354116

DeMarco, J. K. (2014). Assistive technology in school libraries (Yayımlanmamış yüksek lisans tezi). University of Central Missouri, Warrensburg. Erişim adresi: https://centralspace.ucmo.edu/bitstream/handle/123456789/371/DeMarco201430_RP_Assistiv e.pdf? sequence $=7 \&$ isAllowed $=y$

Dengiz, A. Ş. ve Yılmaz, B. (2007). 2004 İlköğretim Programı'nda okuma ve kütüphane kullanma alışkanlıklarına ilişkin öğretmen görüşleri. Bilgi Dünyast, 8(2), 203-229.

Dow, M. J. ve Lakin, J. M. (2012). School librarian staffing levels and student achievement as represented in 2006-2009 Kansas Annual Yearly Progress Data. School Library Research, 15, $2-15$.

Duran, E. ve Ertan Özen, N. (2018). Ortaokul öğrencilerinin Z-Kütüphane ile ilgili görüşleri. ASOS Journal, 6(69), 65-77.

Durukan, A. Y. (2015a). Dijital dünyada okul kütüphaneciliği ve 21. Yüzy1l becerileri. Milli Eğitim Dergisi, 45(208), 106-120. 
Durukan, A. Y. (2015b). Neden kütüphane öğretmenine ihtiyacımız var? Türk Kütüphaneciliği, 29(1), 46-49.

Erol Alkan, S. (2017, 29 Eylül). Okul kütüphanelerinin bilgi okuryazarlığına etkileri (Yayımlanmamış yüksek lisans tezi). Marmara Üniversitesi, İstanbul. Erişim adresi: http://bbytezarsivi.hacettepe.edu.tr/jspui/handle/2062/345

Faba-Pérez, C. ve Infante-Fernández, L. M. (2019). The content disseminated on social media by public secondary school libraries as a reflection of society. The Electronic Library, 37(1), 16-34. doi:10.1108/EL-04-2018-0073

Farmer, L. S. J. ve Safer, A. M. (2019). Trends in school library programs 2007-2012: Analysis of AASL's School Libraries count! data sets. Journal of Librarianship and Information Science, 51(2), 497-510. doi:10.1177/0961000617726128

Fitzgerald, M. A. (2009). Wikipedia: Adventures in the new info-paradigm. M. Orey, V. J. McClendon ve R. M. Branch (Ed.), Educational Media and Technology Yearbook içinde (s. 177-187). Boston, MA: Springer US. doi:10.1007/978-0-387-09675-9_12

Fletcher, J., Grimley, M., Greenwood, J. ve Parkhill, F. (2012). Motivating and improving attitudes to reading in the final years of primary schooling in five New Zealand schools. Literacy, 46(1), 3 16. doi:10.1111/j.1741-4369.2011.00589.x

Fombad, M. ve Jiyane, G. V. (2015). School libraries in South Africa and the post-2015 Millennium Development Goals (MDGs). Libri, 65(3), 191-205. doi:10.1515/libri-2015-0005

Foo, S., Majid, S., Mokhtar, I. A., Zhang, X., Chang, Y. K., Luyt, B. ve Theng, Y. L. (2014). Information literacy skills of secondary school students in Singapore. Aslib Journal of Information Management, 66(1), 54-76. doi:10.1108/AJIM-08-2012-0066

Frank, E. W. (2012). Sağlık ve Eğitim Vakfı (SEV)/AmerikanBord Heyeti (ABH) Okulları öğrenci ve öğretmenlerinin okul kütüphaneleri hakkındaki görüşleri üzerine bir araştırma (A. Aydın, Çeviren). Türk Kütüphaneciliği, 26(1), 97-141.

Gaver, M. (1958). "Every child needs a school library". Opening Address at School Libraries, Information Literacy. Chicago, IL: American Library Association.

Gerrity, C. (2018). The new National School Library Standards: Implications for information literacy instruction in higher education. The Journal of Academic Librarianship, 44(4), 455-458. doi:10.1016/j.acalib.2018.05.005

Gildersleeves, L. (2006). Evaluating evaluation. Aslib Proceedings, 58(1/2), 73-88. doi: $10.1108 / 00012530610648680$

Groves, C. (2019). The power of partnerships academic and high school libraries collaborate for student research success. Reference Services Review, 47(2), 193-202. doi:10.1108/RSR-02-2019-0010

Güneş, A. ve Güneş, F. (2014). Eleştirel okumanın eğitimle ilişkisi ve okul kütüphanecilerinin rolü. Türk Kütüphaneciliği, 28(2), 182-188.

Hashempour, L. ve Taghizadeh Sapchi, A. (2015). Okul kütüphanelerinde renk etkileri ve önemi. Milli Ĕ̈itim Dergisi, 45(208), 51-60.

Hughes, H., Bland, D., Willis, J. ve Burns, R. E. (2015). A happy compromise: Collaborative approaches to school library designing. The Australian Library Journal, 64(4), 321-334. doi:10.1080/00049670.2015.1033380

IFLA. (2015). IFLA School library guidelines. (2nd ed.). Den Haag: IFLA. Erişim adresi: https://www.ifla.org/files/assets/school-libraries-resource-centers/publications/ifla-schoollibrary-guidelines.pdf 
Johnson, A. M., Willenborg, A., Heckman, C., Whitacre, J., Reynolds, L., Sterner, E. A., ... Drerup, S. (2018). Library instruction and information literacy 2017. Reference Services Review, 46(4), 628-734. doi:10.1108/RSR-07-2018-0061

Jones, S. A., Downs, E. ve Jenkins, S. J. (2015). Transparency in the ePortfolio creation process. TechTrends, 59(3), 64-70. doi:10.1007/s11528-015-0854-х

Jorosi, B. N. ve Isaac, G. G. (2008). Teaching information literacy skills in community junior secondary schools in Gaborone, Botswana. Information Development, 24(2), 123-134. doi:10.1177/0266666908091126

Koçak, M. ve Çetintaş, B. (2015). Okul kütüphanelerinde iletişim algısı: Özel okul kütüphaneleri örneği. Milli Ĕgitim Dergisi, 45(208), 158-172.

Kuno, K. (2011). School libraries as the "third place". Lifelong Education and Libraries, 11, 109-118. Erişim adresi: u.ac.jp/dspace/bitstream/2433/152088/1/le111_109.pdf

https://repository.kulib.kyoto-

Küçükcan, B. (2015). Okul kütüphanelerinde mekân tasarımı. Milli Eğitim Dergisi, 45(208), 218-232.

Lo, P., Allard, B., Ho, K. K. W., Chen, J. C., Okada, D., Stark, A., Henri, J. ve Lai, C. (2019). Librarians' perceptions of educational values of comic books: A comparative study between Hong Kong, Taiwan, Japan, Australia and New Zealand. Journal of Librarianship and Information Science, 51(4), 1103-1119. doi:10.1177/0961000618763979

Lo, P. ve Chiu, D. K. W. (2015). Enhanced and changing roles of school librarians under the digital age. New Library World, 116(11/12), 696-710 doi:10.1108/NLW-05-2015-0037

Loh, C. E. (2016). Levelling the reading gap: A socio-spatial study of school libraries and reading in Singapore. Literacy, 50(1), 3-13. doi:10.1111/lit.12067

Martins, J. T. ve Martins, R. M. (2012). Portuguese school libraries evaluation model: an analysis of primary schools' results for the 'reading and literacy' domain. The Australian Library Journal, 61(4), 265-280. doi:10.1080/00049670.2012.10739060

Milli Eğitim Bakanlığı. (2014). Zenginleştirilmiş kütüphaneler (z-kütüphane) etki analiz araştırması: Kısa özet. Ankara: Milli Eğitim Bakanlığı. Erişim adresi: https://dhgm.meb.gov.tr/dosyalar/Z_Kutuphane_Etki_Analizi_Arast\%C4\%B1rmasi.pdf

Milli Eğitim Bakanlığı. (2015). Okuma Kültürü̈ ve Z-Kütüphane Çalıştayı sonuç raporu ve sonrası için planlama. Ankara: Milli Eğitim Bakanlığı.

Milli Eğitim Bakanlığı. (2016). Z-kütüphane. Erişim adresi: http://zkutuphane.meb.gov.tr/Home/Hakkimizda

Milli Eğitim Bakanlığı Z-Kütüphane Haritası. (2019). Erişim adresi: http://zkutuphane.meb.gov.tr:8076/zharita.html

Moorefield-Lang, H. (2014). Makers in the library: Case studies of 3D printers and maker spaces in library settings. Library Hi Tech, 32(4), 583-593. doi:10.1108/LHT-06-2014-0056

Moorefield-Lang, H. (2019). Lessons learned: Intentional implementation of second makerspaces. Reference Services Review, 47(1), 37-47. doi:10.1108/RSR-07-2018-0058

Neufert, E. (2000). Yapı tasarım bilgisi. Ç. Özaslan (ed.). İstanbul: Beta.

Oltmann, S. (2015). Variables related to school media center LGBT Collections. Libri, 65(1), 25-33. doi:http://dx.doi.org/10.1515/libri-2014-0069

Onyebuchi, G. U. ve Ngwuchukwu, M. N. (2013). Information literacy delivery in Nigerian primary schools: A case study of Enugu State, Nigeria. African Journal of Library, Archives \& Information Science, 23(2), 113-121. 
Osadcbe, N. E., Babarinde, E. T., Ekere, J. N. ve Dike, V. W. (2018). Competencies required by teacher librarians for improved primary school library services in Enugu State of Nigeria. African Journal of Library, Archives \& Information Science, 28(1), 61-75.

Öçalan, A. (2010). Halk kütüphaneleri ve okul kütüphaneleri arasındaki işbirliği (Yayımlanmamış yüksek lisans tezi). Hacettepe Üniversitesi, Ankara. Erişim adresi: http://bbytezarsivi.hacettepe.edu.tr/jspui/handle/2062/209

Önal, H. İ. (1985). Türkiye'de okul kütüphanelerinin yönetimi (Yayımlanmamış yüksek lisans tezi). Hacettepe Üniversitesi, Ankara. Erişim adresi: http://bbytezarsivi.hacettepe.edu.tr/jspui/handle/2062/72

Önal, H. İ. (1986). Türkiye'de okul kütüphanelerinin hizmet vermesini etkileyen yönetimsel faktörler. Türk Kütüphaneciliği, 35(1), 17-30.

Önal, H. İ. (1992). Bilgi gereksinimlerinin karşılanması ve okul kütüphaneleri (Yayımlanmamış doktora tezi). Hacettepe Üniversitesi, Ankara. Erişim adresi: http://bbytezarsivi.hacettepe.edu.tr/jspui/handle/2062/566

Önal, H. İ. (2005). Okul kütüphanelerinde derme geliştirme: Politikalar ve dermelerin betimlenmesi. Bilgi Dünyası, 6(2), 193-218.

Önal, H. İ. (2015). Okul kütüphaneleriyle öğrencilerin 21. Yüzyıla hazırlanması. Milli Eğitim Dergisi, 45(208), 233-248.

Önal, H. İ. ve Alaca, E. (2015). Okul kütüphanesi kullanımında öğretmenlerin rolü ve sorumlulukları. Bilgi Dünyası, 16(1), 105-126. doi:10.15612/BD.2015.482

Önal, H. İ. ve Ekici, S. (2012). Okul kütüphanecilerinin görüşlerine göre okul kültürü değerlendirmesi. Bilgi Dünyası, 13(1), 138-164.

Öztürk, H. ve Tağa, T. (2018). Ortaokul öğrencilerinin bir y1llık Z-Kütüphane deneyimleri: Bir durum çalışmas1. Türk Kütüphaneciliği, 32(1), 7-18. doi:10.24146/tkd.2018.27

Paiva, M. de A. M. de ve Ferraz, M. N. (2018). Public libraries and school libraries: Major differences. Transinformação, 30(2), 237-247. doi:10.1590/2318-08892018000200008

Paton-Ash, M. ve Wilmot, D. (2015). Issues and challenges facing school libraries in selected primary schools in Gauteng Province, South Africa. South African Journal of Education, 35(1), 01-10.

Pirola, A., Blasi, G., Cavalli, N., Luschi, P., Pala, P., Pandini, F. ve Zanni, A. (2015). MediaLibraryOnLine (MLOL). Bibliothek Forschung und Praxis, 39(3), 358-377. doi:10.1515/bfp-2015-0043

Polat, C. ve Akkaya, M. A. (2015). Milli Eğitim Bakanlığı bünyesinde hizmet veren lise kütüphanelerinin niceliksel analizi: İzmir Buca örneği. Milli Eğitim Dergisi, 45(208), 173-193.

Ragle, K. S. (2011). The perceptions of high school teachers on the roles and responsibilities of library media specialists. D. Williams ve J. Golden (Ed.). Advances in Library Administration and Organization (Advances in Library Administration and Organization, Vol. 30) içinde (s. 289334). Bingley: Emerald Group Publishing. doi:10.1108/S0732-0671(2011)0000030009

Reynolds, L., McClellan, S., Finley, S., Martinez, G. ve Linares, R. H. (2016). Library instruction and information literacy 2015. Reference Services Review, 44(4), 436-543. doi:10.1108/RSR-082016-0051

Reynolds, L., Willenborg, A., McClellan, S., Linares, R. H. ve Sterner, E. A. (2017). Library instruction and information literacy 2016. Reference Services Review, 45(4), 596-702. doi:10.1108/RSR08-2017-0028 
Rumberger, A. T. (2018). Constructing the literate child in the library: an analysis of school library standards. Berkeley Review of Education, 7(2), 115-137. doi:10.5070/B8bre7232303

Sudhier, K. G. ve Priya, C. D. (2017). Use and awareness of school library blogs: A case study. Annals of Library and Information Studies, 64(2), 137-143.

Şahbaz, N. K. (2012). İlköğretim ikinci kademe öğrencilerinin kütüphane kullanma düzeyleri üzerine bir araştırma. Türklük Bilimi Araştırmaları, 31, 259-274. doi:10.17133/tba.20181

Şahin, A., İşcan, A. ve Maden, S. (2009). İlköğretim öğrencilerinin okul kütüphaneleri ve sınıf kitaplıklarını kullanma durumları (Erzurum ili örneği). Atatürk Üniversitesi Sosyal Bilimler Enstitüsü Dergisi, 13(2), 183-196.

Tabassum, F., Batool, S. H., Ameen, K. ve Hassan, M. (2019). Status of school libraries and developmental issues in Pakistan. Global Knowledge, Memory and Communication, 68(4/5), 377-391. doi:10.1108/GKMC-08-2018-0070

Tedd, L. A., Ellis, D., Lonsdale, R. ve Armstrong, C. (2006). The role of the university library in supporting information literacy in UK secondary schools. Aslib Proceedings, 58(6), 553-569. doi:10.1108/00012530610713623

Tuna, M. (2005). Ankara'daki üniversitelere bağlı özel ilköğretim okul kütüphanelerinde derme geliştirme (Yayımlanmamış yüksek lisans tezi). Ankara Üniversitesi, Ankara. Erişim adresi: http://bbytezarsivi.hacettepe.edu.tr/jspui/handle/2062/138

Udina, K. (2014). Emerging technologies or technophobia in school libraries survey: technology and learning in school libraries in Croatia. S. Kurbanoğlu, S. Špiranec, E. Grassian, D. Mizrachi ve R. Catts (Ed.), Information Literacy. Lifelong Learning and Digital Citizenship in the 21st Century içinde (s. 291-296). Springer International Publishing.

Valenza, J. ve Hobbs, R. (2016). School librarians as stakeholders in the children and media community: A dialogue. Journal of Children and Media, 10(2), 147-155. doi:10.1080/17482798.2015.1127841

Wang, X., Shen, D., Chen, H. ve Wedman, L. (2011). Applying web analytics in a K-12 resource inventory. The Electronic Library. doi:10.1108/02640471111111415

Yıldırım, A. ve Şimşek, H. (2018). Sosyal bilimlerde nitel araştırma yöntemleri. Ankara: Seçkin Yayınc1lik.

Y1lmaz, B. (1998). Halk kütüphaneleri-okul kütüphaneleri arasında işbirliği ve Türkiye'de durum. Türk Kütüphaneciliği, 12(2), 110-130.

Y1lmaz, E. (2015). Eğitimde okul kütüphaneleri: Türkiye'de durum. Milli Eğitim Dergisi, 45(208), 259286.

Yılmaz, M. (2015). Okul kütüphanecisinin matematiksel yöntem ile seçimi: OWA (Sıralı Ağırlıklandırılmış Ortalama). Milli Eğitim Dergisi, 45(208), 200-217.

Yin, R. K. (1984). Case study research: Design and methods. Beverly Hills, Calif: Sage Publications.

Yüksel İleri, F. (2011). Okul kütüphanelerinde bilgi okuryazarlığl eğitimi ve bir örnek: Marmara Eğitim Kurumları Illkögretim Okulu (Yayımlanmamış yüksek lisans tezi). Marmara Üniversitesi, İstanbul. Erişim adresi: http://bbytezarsivi.hacettepe.edu.tr/jspui/handle/2062/340

Zinn, S., Stilwell, C. ve Hoskins, R. (2016). Information literacy education in the South African Classroom: Reflections from teachers' Journals in the Western Cape province. Libri, 66(1), 3144. doi: 10.1515/libri-2015-0102 


\section{Summary}

School libraries are institutions that contribute to students' achievement and intelligence. These institutions have a vital role in education and teaching activities at schools. Being in the center of learning activities, as a place, school libraries have a crucial position in improving problem solving skills and innovative ideas. The school library is identified as an organization that enables pupils to be proficient and avid readers, and to have intelligence about their environments, and to folow opportunities in subsequent conditions (Gaver, 1958). Advances in technology provide opportunities in many sectors. Online education opportunities and increasing interest in these applications caused the transformation of learning environments. In this regard, school libraries need to keep up with the changes. In this understanding, beside the traditional services, the new approaches adopted in school libraries contribute to the school curriculum. These libraries with their spatial designs become attractive spaces where pupils can meet their peculiar information needs.

As is in other countries, the projects and practices related to school libraries are carried out by the Ministry of National Education in Turkey. One of the projects for school libraries in Turkey is the z-library project. Since 2014, the project, which has been launched by the Ministry of National Education, proposes to improve the functions of libraries in schools in conformity with the requirements of the era. Z-Library is characterized as a social learning place that allows pupils to interact with information, supports teaching and learning activities, and provides relaxation spaces in schools with its aesthetic and ergonomic design (Milli Eğitim Bakanlığ1, 2016). This definition also points to the purpose of the establishment of $z$-libraries. From this rationale, it can be claimed that the essential objective of z-libraries is to transform school libraries into social learning spaces. However, the physical improvements of libraries and the increase in the number of materials are not satisfactory to accomplish this intention. In addition, it is necessary to expand the library services, strengthen the quality of the services and set up a sufficient environment for various usage purposes. This study designs to investigate the prevailing approaches and managerial frameworks of school principals and teacher-librarians about z-libraries that depict the technological transformation of school libraries in Turkey. In this regard, the study scrutinizes the minds of school principals and teacher-librarians regarding the management of z-libraries located in Çankaya district of Ankara, Turkey. Additionally the current conditions, and practices carried out in such libraries are also observed in the study.

The problem statement of this research is determined as "established as a social learning environments, z-libraries in Çankaya district of Ankara have managerial issues." Based on the research problem, the succeeding questions are inspected in schools having z-libraries in the Çankaya district of Ankara.

RQ1. What are the intended use of z-libraries and current spatial space conditions?

RQ2. Based on the school principals and teacher-librarians' judgments, what kind of problems are experienced in the administration of z-libraries?

RQ3. In the light of school principals and teacher-librarians' examinations and approaches, how technological facilities and other materials are utilized in z-libraries?

In line with the purpose, and the problem statement, this study is based on a descriptive research. Descriptive research is expressed as a research aimed at defining a given situation as accurately and rigorously as possible (Büyüköztürk, Kılıç Çakmak, Akgün, Karadeniz and 
Demirel, 2017, p. 24). The study also represents the case study which is one of the qualitative research methods.

Semi-structured interview and direct observation techniques were employed to gather data. In this context, a form consisting of questions to detail the practices and approaches in $\mathrm{z}$ libraries was evolved. In order to improve this form, preliminary unstructured interviews were organized with the school principals or teacher-librarians in four schools. In these interviews, the existing conditions of z-libraries was outlined and the interview form to be utilized in the interviews in other schools was redesigned.

Following the development of the form, the z-library map published on the official web page of the project is used and it was identified that 20 schools have z-libraries in Çankaya district of Ankara (Milli Eğitim Bakanlığı Z-Kütüphane Haritası, 2019). In the end, the data were accumulated from twelve schools including four elementary schools, four secondary schools and four high schools. In addition, the automation system and the official z-library website were used for finding the space and bibliographic record data.

In relation to the first research question (RQ1); the results display that three schools do not have a library space before the establishment of z-library. Furthermore, the results related to the use of the z-libraries indicated that the libraries in elementary and secondary schools are extensively used in reading hours while those in high schools are employed for studying for courses, exams and national exams. On the other hand, it is anticipated that the three schools organize seminars, conferences, author talks in their z-libraries. Z-libraries in three schools are used for internet access. It is thought that the awareness of the school principals and teacherlibrarians, the projects and the efforts to comply with the international programs are efficient in the diversity of activities in the libraries.

The results also demonstrate that there is a difference between schools in the use of computers and other technological facilities in z-libraries. In this regard, internet access is actively used in three z-libraries while it is not used in nine z-libraries. It is also declared that in one z-library, the projector and presentation screen are used in seminars. Moreover, it is seen that the computers in one z-library are broken and they are required to be renovated. Results regarding the use of the automation system report that the number of cataloged resources in the system is relatively low, and in some z-libraries, the circulation modules of the system are not used and the circulation data are recorded to a notebook. In connection with the second research question (RQ2), the results highlight that the technical facilities in z-libraries (i.e. automation systems, computers, and software) need to be maintained.

The results referred to the third research question (RQ3) point out that the school principals and teacher-librarians are experienced numerous problems since the establishment of their z-libraries. It is possible to express that the experienced problems (i.e. lack of professional personnel and understanding, lack of supposed use of the z-libraries mentioned in establishment phases, funding problems, need for professional assistance in the field of information management, maintenance issues of technological equipments), are related to management and sustainability of z-libraries. In this regard, there is a need for the development of innovative services that will strengthen z-libraries in schools as a social learning environment and guidance on this issue.

Lastly, it is considered that the various problems practiced in the z-libraries in twelve schools are not concerned with the establishment of z-libraries, but their sustainability. 